\title{
We need to appreciate common synanthropic plants before they become rare: Case study in Latgale (Latvia)
}

\author{
Baiba Prūse ${ }^{1,2,3, *}$; Raivo Kalle ${ }^{4}$; Gabriella Buffa ${ }^{1}$; Andra Simanova ${ }^{2,3}$; \\ Ieva Mežaka² and Renata Sõukand ${ }^{1}$
}

\begin{abstract}
Local ecological knowledge holds great potential in contributing to sustainable resource management and conservation activities. For this reason, the authors choose to analyse an ethnobotanical dataset from the Baltic Sea region by exploring the relationship between plants and humans on the basis of three main categories: habitat characteristics, distribution in the wild and plant sensitivity to human impact beyond physical distance. The study provides empirical evidence of widespread usage of socalled common species which are widely distributed in the territory and benefit from human activity. When considering the data via the intensity of use, based on detailed use-reports (DUR), the main category is shown to be apophytes (1001 DUR), followed by anthropophytes (426), hemeradiophores (255) and hemerophobes (54). The authors highlight the co-dependency of plants and humans in the medicinal and wild food domains and stress the need for integrated management strategies where local community knowledge plays a part.
\end{abstract}

Keywords: Common Species; Conservation; Ethnobotany; Synanthropic Plants.

1 Ca’ Foscari University of Venice, Via Torino 155, 30172, Mestre, Venice, Italy.

2 Institute for Environmental Solutions, "Lidlauks", Priekuļu Parish, Priekuļu County, Latvia.

3 University of Latvia, Raiņa bulvāris 19, Riga, Latvia.

4 University of Gastronomic Sciences, Piazza Vittorio Emanuele 9, 12042, Pollenzo, Bra, Cn, Italy.

* Corresponding author $\bowtie$. E-mail address: BP (baiba.pruse@unive.it), RS (renata.soukand@unive.it), GB (buffag@unive.it), AS (andra.simanova@videsinstituts.lv), IM (ieva.mezaka@videsinstituts.lv), RK (raivo.kalle@mail.ee)

\section{SIGNIFICANCE STATEMENT}

The authors seek to understand the relationship between plant use and plant sensitivity to human impact beyond physical distance. To do so, the authors specifically choose to analyse an ethnobotanical dataset from the Baltic Sea region and divide the named plants into various categories based on human - plant relationships. The authors note the great importance of synanthropic plants in both the human diet and medicinal applications. We highlight the existing work and continued need to integrate local ecological knowledge into conservation actions in order to safeguard biocultural diversity. 


\section{INTRODUCTION}

Ecological change and the decline of plant genetic resources are among the factors behind the loss of knowledge regarding traditional plant use (Hanazaki et al. 2013). Not only does the disappearance of wild taxa affect the practice of active use but it might also cause certain damage to cultural heritage as traditional knowledge plays a part in defining cultural identity (Bharucha and Pretty 2010). While discussing change in traditional ecological knowledge, environmental degradation has been an important factor from the perspective of academic discussion (Tang and Gavin 2016; Aswani et al. 2018). The Millennium Ecosystem Assessment (2005) lists several natural and human-induced factors which cause changes in the ecosystem, including the ongoing land use and habitat transformation. However, many habitats, e.g. hedgerows, grasslands, and road verges, have evolved through traditional agricultural practices (Bignal and McCracken 1996; Halada et al. 2011) and depend on the continuation of human activities to maintain their species composition, structure and function. Despite not being natural, semi-natural habitats are known for the high biodiversity they host and the services they provide (Fantinato et al. 2018). Moreover, scholars stress the historical development of ecosystems in which prehistoric societies played a great part in their creation (Albuquerque et al. 2018). In this respect, conservation strategies should not exclude people but rather greatly enhance the coexistence of nature and humans (Carter et al. 2012) or their symbiotic relationship (Ksenzhek and Volkov 1998). The importance of the diversity of all forms of life brings us closer to the general concept of biocultural diversity (Maffi and Dilts 2014) and the co-dependency of plants and humans (The Shenzhen Declaration 2017; Raven 2018). Biocultural diversity utilizes the diversity of nature (Maffi and Dilts 2014). However, few studies have explored human dependence on common species which "shape much of the world around us" (Gaston 2008). Until now, limited studies have emphasized the importance of common species; however, existing studies suggest that dominant or common species "in natural communities play a key role in conferring short-term resistance to reductions in ecosystem function, as rare and uncommon species are lost" (see Smith and Knapp 2003, p. 515). However, common species "have been the subject of rather little explicit attention, either from ecologists or from conservation biologists" (Gaston 2008, p. 73). While discussing plant conservation strategies, attention is only rarely given to widely distributed plant taxa (see Vila-Ruiz et al. (2014) on residential yards). Other scholars have also noted that little value is placed on marginal lands (Marouf et al. 2015). Gaston (2011) adds that "although common species are those with which we are inevitably most familiar, the state of being common is itself rare" (...) "common species lie at the very heart of the biodiversity crisis" (p. 354359). This in turn leads us to the overall question of biodiversity and consequently to human well-being (see FAO 2019). With regard to the above, we would like to provide a closer look at the concept of common species through the lens of ethnobotany, and thus the core aspect of this study.

As noted by Gaston (2010), common species are as important as rare ones, due to their importance in supporting ecosystem services. A growing number of studies have emphasized the importance of common species among various ecosystems (Winfree et al. 2015; Frimpong 2018), including the importance of weeds (Stepp and Mowerman 2001; Zimdahl 2018) and neglected and underutilized species in supporting human needs (Hunter et al. 2019). The academic arena includes numerous discussions related to various nature conservation approaches (see Mulder and Coppolillo 2005) such as the concept of looking beyond borders of protected areas (Mora and Sale 2011; Western et al. 2015; Heywood 2019).

The link between traditional knowledge and resource management, as well as theoretical studies on plant availability and their use, e.g. optimal foraging theory, is not new phenomenon and has been developed by many scholars (e.g. Schultes 1994; Cunningham 2001; Bussman 2002, Albuquerque 2008; Albuquerque et al. 2015; Shrestha and Medley 2017), although recent studies have stressed the need to better integrate ethnobotanical results in practice (Albuquerque et al. 2019), particularly while prioritizing plant lists for conservation activities (Heneidy et al. 2017). In respect to plant taxa and their management, less than three out of 100 useful wild species worldwide are sufficiently protected through in-situ or ex-situ conservation actions (Khoury et al. 2019); in Latvia approximately 235 vascular plant species are included in the list of specially protected species with additional taxa listed as specially protected with exploitation limits (Cabinet of Ministers No 396 2000). Khoury et al. (2019) also includes ethnobotanical knowledge while defining useful wild plants.

Based on the above, our aim is to gain a glimpse into the relationship between plant use and plant sensitivity to human impact and the ecological characteristics of taxa through the lens of an ethnobotanical study from the Baltic Sea region. The objectives of the study are twofold. Firstly, to assess the proportion of plants used among local communities on the basis of three categories: distribution, habitat, and plant sensitivity to human impact. Secondly, to draw attention to the need to notice and protect common synanthropic plants needing human attention, as 
these provide security food and a medicinal reservoir. We propose as a hypothesis that people prefer to use plants that are more anthropophilic, e.g. plants which need or benefit from human influence.

Latgale region (Latvia) was chosen as a case study and our research goes beyond the classical ethnobotanical analysis. The region has already been studied with regard to food (Prūse et al. 2020 under revision) and medicinal plant applications from an ethnobotanical perspective (Simanova et al. 2020) which provides a list of ethnobotanically used plants. We categorize the used taxa and discuss the results of our search for the dominant characteristics of the ethnobotanical dataset, while proposing how ethnobotanical knowledge of the region might support nature conservation strategies on a local scale.

\section{MATERIAL AND METHODS}

The study region (Figure 1) is rich in lakes and the territory is primarily covered by available agriculture land (43\%) and forests (41\%) (DNAP 2012). Historical notes from the work conducted by Lehmann (1985) provide information about the Latgale region (including the study area) indicating the presence of 819 vascular plant species (Suško and Evarts-Bunders 2010). Depending on the source, the number of vascular plants for the whole of Latvia varies between 1800 and 1937 species (Tabaka et al. 1988; Gavrilova and Šulcs 1999; Priedītis 2014; Nikodemus et al. 2018). Parts of the study sites are within Rāznas National Park (Dagdas novada pašvaldība 2018).

The fieldwork took place in Dagda municipality (Latgale region) in July 2017, during which the data were collected using semi-structured interviews following pseudo-random and snowball methods. Seventy-three interviewees, with an average age of 63 years, provided responses to questions regarding wild plant species used as medicine and food. Both past and current practices of plant use were recorded. The Code of Ethics of the International Society of Ethnobiology (ISE 2006) was followed, and prior informed oral consent was obtained from all interviewees. Voucher specimens were collected with the interviewees and deposited at the Estonian University of Life Sciences herbarium (TAA), bearing numbers LGA001-120 and herbarium numbers TAA0146373495. The dried plant samples are deposited at the Herbarium of DAIS at Ca' Foscari University of Venice (UVV), bearing numbers UVVDLGA001-71. For a full description of the data collection methodology and description of interviewees, see Simanova et al. (2020).

\section{Categorization}

The study analyses ethnobotanically significant plants on the basis of three different categorization approaches in order to understand the importance of useful plants in relation to humans and within the ecosystem. The first approach evaluates the distribution range of species in the ecosystem, the second discusses the habitats in which these plants can be found, while the third addresses plant sensitivity to human impact.

\section{Distribution range}

Following the vascular plant catalogue of Latvia by Gavrilova and Šulcs (2005), for each wild and cultivated taxon the distribution range across the country e.g. common or rare in the wild, and its naturalization status, e.g. escaped plants which commonly naturalize, were recorded. Additionally, an encyclopaedia on Latvian plant taxa was used for deriving information for 7 plant taxa as the data were missing from the reference source (Prieditis 2014), as well as for adding conservation status (Prieditis n.d.), if any, with regard to species listed in the Latvian Red Book (Andrušaitis 2003). For 20 plant taxa no distribution range was defined in the given source, as 18 of these taxa were cultivated species and 2 were purchased in a shop (Additional file 1).

\section{Habitat}

The occurrence of plant taxa was listed between several habitats on the basis of the information provided in the encyclopaedia of Latvian flora (Prieditis 2014). For comparative purposes, the various habitats of occurrence were combined into larger categories. In this respect, one or more of 10 habitat groups were assigned to each taxa: 1) along roadsides and railways; 2) in nutrient poor habitats including gravel, loam, sand, dolomite, and dunes; 3) in humaninfluenced environments which are directly modified by humans including nutrient-rich habitats, at buildings, gardens; 4) on fallow lands; 5) in pastures; 6) in various forest habitats including pine forests and in shrubs; 7) across various habitats including open, dry and other; 8) in various meadows (excluding wet habitats) including forest edges and hillslopes; 9) in wasty places; and 10) in wet and swampy habitats, bogs and wet forests. For most of the taxa, their habitats were not restricted to only one type. Thirty-three taxa (mostly cultivated) were either not included or had no information on their occurrence in the online Latvian flora encyclopaedia. In such cases the habitat of occurrence was left blank. The limitation associated with the above division of habitats is two-fold: this information does not necessarily reveal where people 


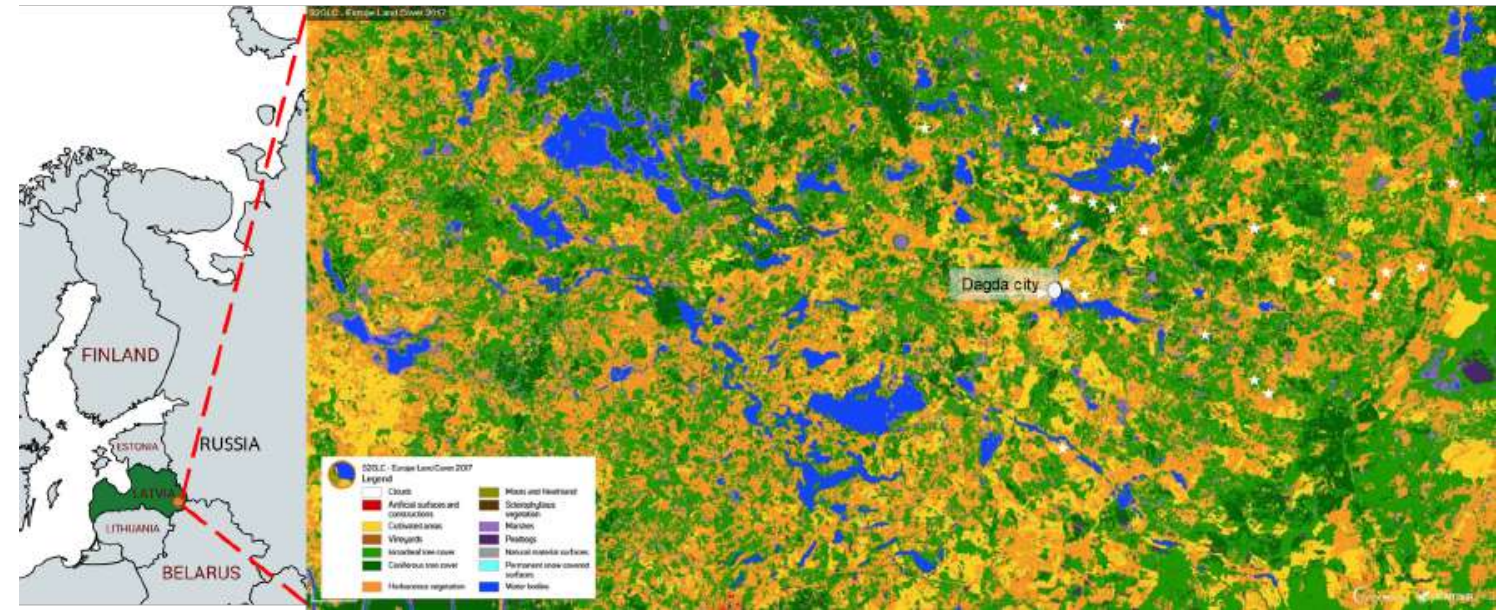

Figure 1. Map of the study area including land cover representation ( $\star-27$ study villages \& populated areas).

collect plants and the description is quite vague as it is not directed to the study region specifically but rather the whole of Latvia. Additionally, this categorization does not include any emic viewpoints and thus is largely based on an outside or so-called etic perspective.

\section{Sensitivity to human impact}

Many ethnobotanical studies limit plant classifications to folk botanical classification (Poncet et al. 2015), habitat (Beltrán-Rodríguez et al. 2014) or ecosystem division (Ouédraogo et al. 2014), while only two recent studies on Estonian ethnobotany have addressed also categorizations of sensitivity to humans, although it was only applied to historical data on the use of medicinal plants (Sõukand and Kalle 2011; Sõukand and Kalle 2012).

We followed the forementioned works and applied Kukk's (1999) approach in order to describe plant and human relationships based on dependency rather than the plant's physical distance from humans. Sensitivity to human impact is assessed on the basis of the positive or negative effect of human activities on the plant. More specifically, for some plant taxa, humanmodified environments are the only means to survive. Kukk (1999) names four categories of plants based on their sensitivity to human impact:

(1) anthropophytes (dependent on human activity, the group also includes cultivated plants),

(2) apophytes (need human interaction),

(3) hemeradiophores (indifferent to human activity, can grow in both human-disturbed and untouched habitats), and

(4) hemerophobes (avoid human disturbance).

In Latvia, similar terminology regarding apophytes and anthropophytes is used by Laiviņš (1989) reflecting, as with Kukk (1999), the status of their presence in the flora (native vs. alien). However, the Laiviņš (1989) study lacks the hemeradiophore and hemerophobe categories, and therefore we use Kukk's (1999) categorization which is based on Estonian flora. Nonetheless, the short geographical distance and shared climate between the two countries (Rimkus et al. 2018) allows for assuming that the similarity of the applicable categories is very high. Kukk's (1999) categorization is based on his own observations and the work of Enari (1944) and Rebassoo (1962) (see Kukk 1999).

We further considered the sensitivity of human impact on the proportion of taxa that was actually used; as, for example, we cannot speak about birch (Betula spp.) being a hemeradiophore, but would rather need to allocate it to the apophyte group, since it needs to attain a certain age or thickness in order to be ready for tapping sap and this is mainly possible when the tree is looked after, to a greater or lesser extent, by the users. The same applies to Ribes nigrum L., Quercus robur L., Tilia cordata Mill. and Acer platanoides L., all of which grow in human-induced landscapes (for the full list see Additional file 1).

Following such reasoning, we assigned all taxa to one of the four categories of sensitivity to human impact.

\section{Analysis}

Using the list of plants derived from the ethnobotanical field study, we compiled an Excel spreadsheet (Additional file 1) in which every used taxon was associated with all habitat categories reported in the literature sources. As no single source used for classification was exhaustive, or even the list of plants univocally interpretable, we had to perform several adjustments.

- On occasions in which the interviewee described 
an application only on a class or family level and/or it was not possible to identify the plant, the plants were excluded from the analysis, i.e. Poaceae and Polypodiopsida.

- In some cases, where the identification was only made at the genus level and no herbarium specimen was available, the common taxa was selected from the Latvian flora data base (Prieditis 2014), e.g. for Betula spp. the common species Betula pendula Roth was chosen. In cases in which numerous herbarium specimens were available with different species of the same genus, the most common species was included in the data analysis based on the available information on its occurrence in the wild provided in the plant encyclopaedia of Priedītis (2014). In a few instances, two species were named where the distribution was different, e.g. Mentha x piperita L. (rarely runs wild), Mentha longifolia (L.) L. (runs wild) (Prieditis 2014). In such cases, the most human-preferring taxon, e.g. apophytes, was included in the analysis.

- Eighteen taxa were not named in Kukk's (1999) classification and therefore the category was assigned by the current authors. Sixteen of these taxa were cultivated plants and thus classified as anthropophytes. Corylus avellana L. and Viburnum opulus L. were assigned to the apophyte category. Both taxa are found in the wild and are also planted near human settlements either for ornamental or nutritional supplementation purposes (Priedītis 2014, EvarteBudere et al. 2014, Dabas dati 2020). In cases of uncertainty, interviewee comments were analysed.

- In cases in which the distribution of taxa was not provided by Gavrilova and Šulcs (2005), the Latvian plant encyclopaedia of Prieditis (2014) was used to complete the missing information. However, for most of the 20 cultivated taxa this data was not provided in either of the two sources and thus left blank.

Detailed use-reports (DUR) were used for the calculations as they are the best means of assessing the intensity and diversity of use for the named taxa. Both past and present uses were included in the analysis; however, we also compared past and current uses in order to establish whether changes over time have occurred.

For the analysis, there were a total number of 139 taxa deriving from 55 plant families. This included 116 taxa from 50 plant families for medicinal uses, and 73 taxa from 38 families for food uses. The total number of DUR analysed, including both medicinal and food uses, was 1736. The number of uses for medicinal application was 841 DUR, while that for food was 895 DUR. For food taxa, only wild plant taxa were considered with a few exceptions: the cultivated plant had a special manner of preparation, it was not cultivated for food purposes, or the plant part used was not regularly used as food. For medicinal plant taxa, potted or house plants were also included in the analysis. This might introduce a slight bias while comparing anthropophyte categories between medicinal and food uses.

In order to test the study objectives, Pearson's correlation coefficient ( $\mathrm{R}$ version 3.5.3.) was calculated between the four categories of sensitivity to human impact and DURs. The categories of sensitivity to human impact were converted into a numerical scale (NS) (anthropophytes - 4; apophytes - 3, hemeradiophores -2 ; hemerophobes -1 ).

\section{RESULTS}

\section{Habitats}

The main taxa used by interviewees, namely $B e$ tula pendula, B. pubescens Ehrh., and Vaccinium myrtillus L. (> 100 DUR), grew in habitats which are rarely considered important in terms of conservation. More precisely, based on the categorization of Prieditis (2014), out of 139 taxa from the ethnobotanical data of the Dagda region, thirty-three taxa grew along roadsides/railways, thirty-nine taxa grew in wasty places and thirty-seven grew in humaninduced, nutrient-rich habitats (see Figure 2, Table 1, Additional file 1). More than half of the taxa cited by interviewees grew in different co-shared habitats. For example, Achillea millefolium L. grows in gravel and sand pits, on roadsides and in various dry wasty places; and Rumex thyrsiflorus Fingerh can be found in dry meadows, on fallow lands, on the slopes of riverbanks and in wasty places (Prieditis 2014).

More than half of the taxa are common or fairly common in occurrence in Latvian flora (Additional file 1). Only two taxa are listed in the Latvian Red Book (Andrušaitis 2003) within the third category (rare species which are not becoming extinct but might become extinct due to a limited number of individuals or limited areal distribution): Allium schoenoprasum L. and Allium ursinum L. Allium ursinumis L. is also included in the specially protected plant list issued by the Cabinet of Ministers No 396 (2000).

\section{Distribution range}

The ethnobotanical data reveals the high dependency of local communities on common or fairly common taxa across Latvian flora (Figure 3). 
Table 1. Occurrence in the environment of plants of Latvian flora cited by interviewees from communities in Dagda municipality, based on the Prieditis (2014) encyclopaedia.

\begin{tabular}{lc}
\hline \hline \multicolumn{1}{c}{ Habitat } & Number of taxa \\
\hline \hline along roadsides and railways & 37 \\
in nutrient poor habitats including gravel, loam, sand, dolomite, and dunes & 16 \\
in human-influenced environments including nutrient-rich habitats & 38 \\
on fallow lands & 14 \\
in pastures & 4 \\
in various forest habitats including pine forests and in shrubs & 42 \\
across various habitats including open, dry and other & 8 \\
in various meadows (excluding wet habitats) including forest edges and hillslopes & 38 \\
in wasty places & 39 \\
in wet and swampy habitats, bogs and wet forests & 37 \\
\hline \hline
\end{tabular}
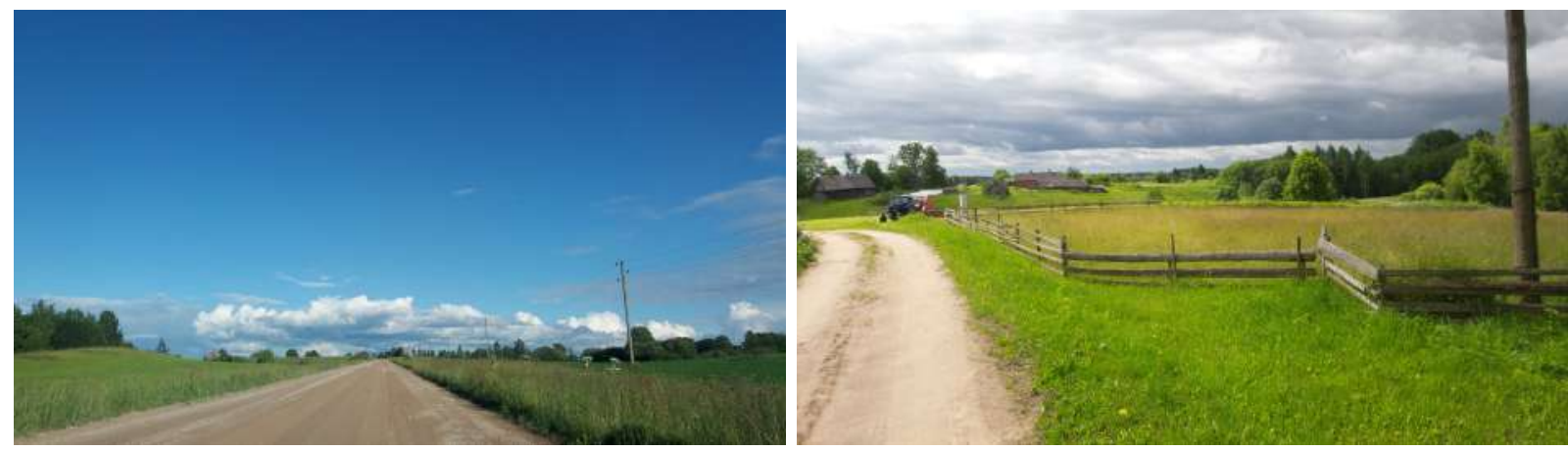

Figure 2. Typical roadsides in the study area of Dagda municipality, Latvia. Credit: BP \& RS.

\section{Plant sensitivity to human impact}

The main plant category among all taxa is anthropophytes, which is followed by apophytes (Figures 4 and 5).

While comparing the division between applications, anthropophyte taxa are more represented among medicinal uses whereas apophytes are fairly common among both food and medicine uses. A possible explanation for this difference may be linked to the constantly changing need for various medicinal taxa, and thus it is easier for people to operate within the better-known environment. Most of the anthropophytes are cultivated taxa, of which 12 are associated with food use and 34 with medicinal use. Only one shared taxon, Armoracia rusticana P.Gaertn., B.Mey. \& Scherb, appears as cultivated within the apophyte category (Additional file 1).

The situation is different when considering the data via the intensity of use, based on detailed usereports (DUR), where the main category is shown to be apophytes (1001 DUR), followed by anthropophytes (426), hemeradiophores (255) and hemerophobes (54) (Figure 6). The number of taxa for apophytes is lower in comparison to that of anthropophytes, but the diversity of use is higher. An interviewee (woman born in 1965) reported a past use of Potentilla erecta L. as a medicinal remedy which can no longer be found by the interviewee. This and similar narratives inspired us to analyse past uses separately. Considering the taxa only named as a past use (13 taxa), most fall under the apophyte and anthropophyte categories and only three out of 13 taxa fall under the hemeradiophore group: Oxalis corniculata L., Melampyrum nemorosum L. and Helichrysum arenarium (L.) Moench.

It is important to note that most of the taxa reported by interviewees as either disappeared or not growing nearby were apophytes (e.g. Valeriana officinalis L., Potentilla erecta). An interviewee born in 1976 mentioned that Carum carvi L. has died out, sharing their memory that "when my mother gathered Carum carvi it was widespread in the meadows".

Among the apophyte group, Fragaria vesca L. (Figure 7) stands out with the highest DUR for food (74 DUR) and Betula spp. (59 DUR)) for medicinal application.

The taxon with the highest DUR among the anthropophyte group for medicinal application is Matricaria chamomilla L. (41 DUR), whereas for food it is Mentha sp. (Mentha $\times$ piperita (14 DUR)). To note, anthropophyte taxa also include escaped plants which commonly naturalize. For hemeradiophores, the main 


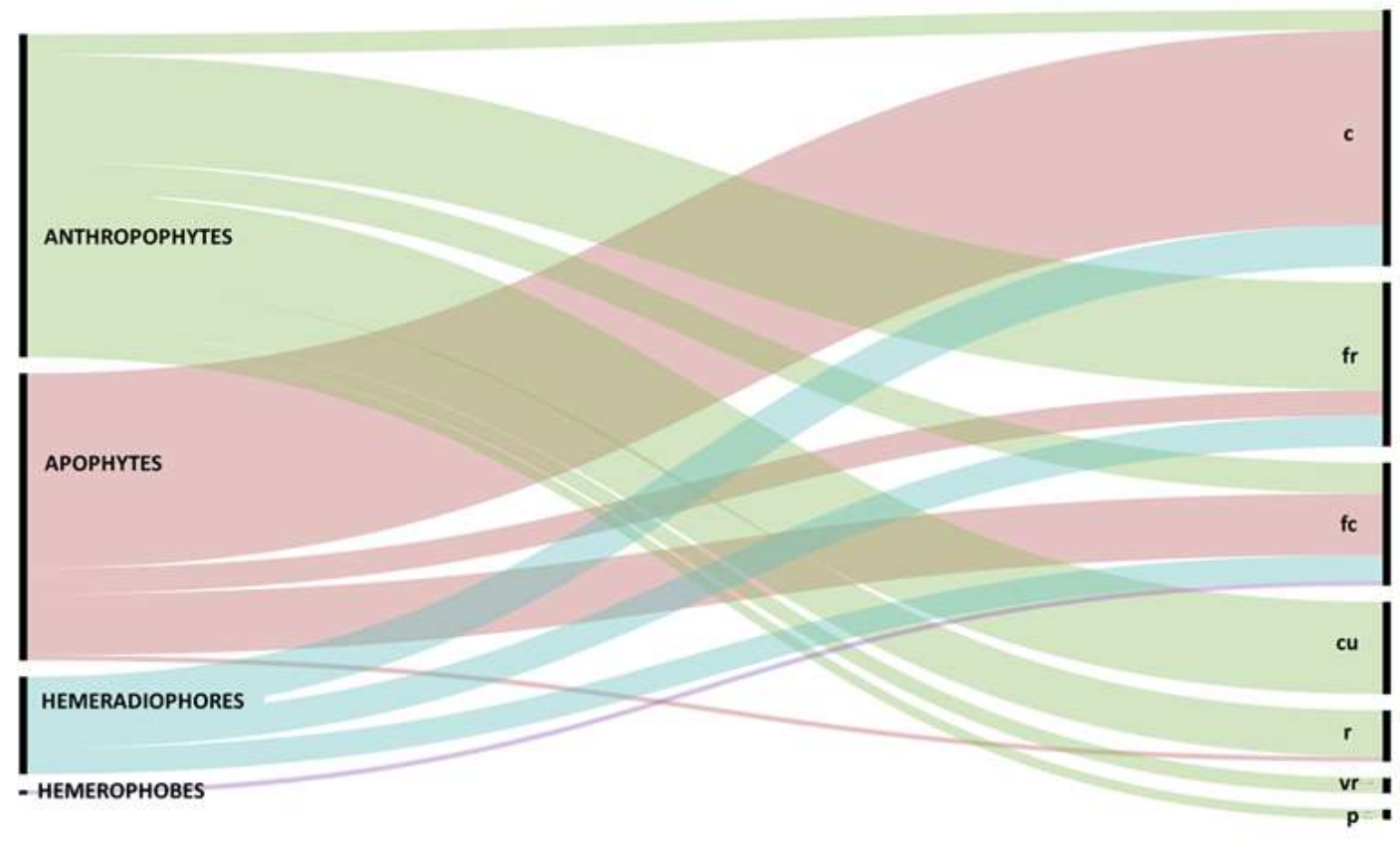

Figure 3. Occurrence of plant taxa named by interviewees that are found in the wild based on Gavrilova and Sulcs (2005) apportioned by the number of taxa in each of the four categories of sensitivity to human impact ('cu' - cultivated; 'p' - purchased; 'c' - common; 'fc' - fairly common; 'fr' - fairly rare; 'r' - rare; 'vr' - very rare).

taxon based on DUR was Vaccinium myrtillus for both food (83 DUR) and medicinal application (22 DUR). The only taxon within the hemerophobe group for both food and medicinal application is Vaccinium oxycoccos L. (Figure 8). This might be explained by the nature of hemerophobe taxa, which are found far from human-influenced environments and thus difficult to reach.

For calculation, the total number of DUR was summed for each category of sensitivity to human impact $\left(1 \mathrm{NS}_{\text {hemerophobes }}-54 \mathrm{DUR}\right.$; $2 \mathrm{NS}_{\text {hemeradiophores }}-255$ DUR; $3 \mathrm{NS}_{\text {apophytes }}-1001$ DUR; $4 \mathrm{NS}_{\text {anthropophytes }}-426$ DUR). Based on the analysis of Pearson's correlation coefficient the correlation is positive but not significant $(R=0.59)$.

\section{DISCUSSION}

A Latgalian man born in 1937 noted that "what grows around needs to be used", which explicitly describes our main results. Our analysis indicates that both medicinal and food plant uses in Latgale region (Latvia) highly depend on apophyte and anthropohyte taxa, which goes hand in hand with the idea of 'co-dependency' as emphasised by Raven (2018). 'Co-dependency' as introduced by Raven presents the following two-way relationship: "We all need plants, depending on them absolutely for our very existence, but in the Anthropocene, plants also need us for their survival" (p. 12). This, in turn, is quite alarming as there is a lack of management strategies particularly for apophyte taxa since most of these taxa are widely distributed and hold no special status, except for $\mathrm{Al}$ lium schoenoprasum which is listed in the Latvian Red Book (Andrušaitis 2003). However, taxa that benefit from human activities not only hold high importance for biologically valuable grasslands (e.g. indicator species Polygala vulgaris L., Briza media L.), umbrella species (Valeriana officinalis) (Rūsiņa et al. 2005; Baroniņa 2016; Auniņš et al. 2013) and various applications as food and medicine, but they also have a tight connection with cultural elements. Widely used apophyte taxa such as Fragaria vesca, Rubus idaeus L., Rumex spp., and Carum carvi are named in Latvian Folk Song collections (listed under the UNESCO programme) dating back to 1880 as well as in Latvian beliefs, e.g. collection of Pēteris Šmits 1940 - 1941 (Sile et al. 2019). For example, Urtica spp., which exhibits a high number of DUR in the apophyte category, has been an important plant across the Latvian territory even before the introduction of Christianity (Suomela et al. 2018). The Latvian collection of Folk Songs likens the ability of plants to sting to difficulty in human life (Dainu Skapis n.d.). The collection of Latvian beliefs indicates various applications of nettles including as a hair 


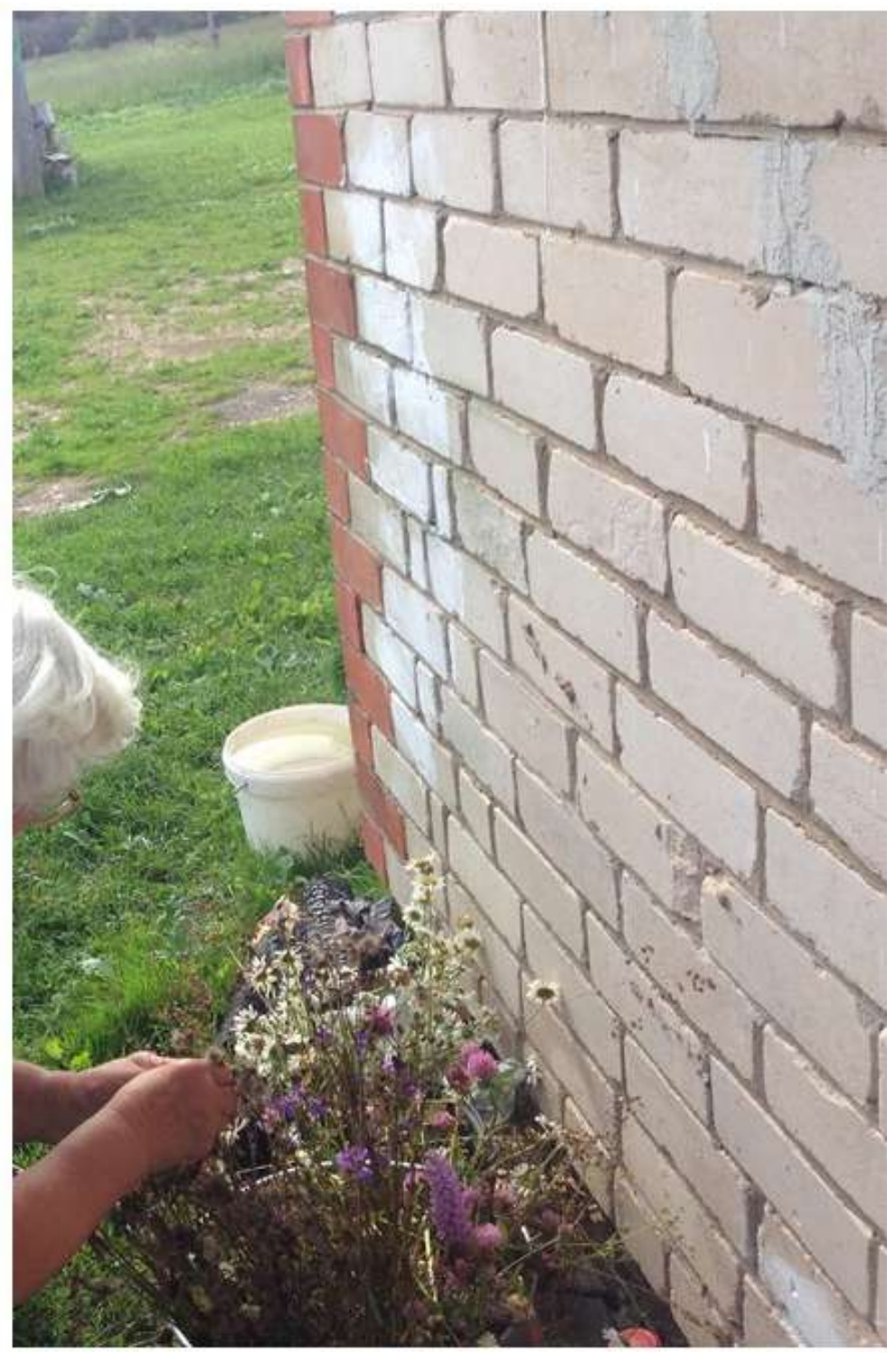

Figure 4. Synanthropic taxa including Leucanthemum vulgare (Vaill.) Lam. and Carum carvi L. at the side of an interviewee's house. Credit: IM.

treatment, to alleviate headache and in the household to combat fleas (Sile et al. 2019; AiLab n.d.). In addition, Carum carvi has a very deep history as a food plant dating back to medieval towns in the 14 th century (Brown et al. 2017), and is noted as one of the plants symbolizing Latgalian identity (Svilāns et al. 2012). These are only few examples providing a snap shot of the importance that apophyte species hold for both habitats and human use. Unfortunately, Halada et al. (2011) has already noted that numerous European habitat types which depend on or benefit from low-intensity human activity, in this case agricultural management throughout Europe, experience rather worse conservation status compared to nonagricultural habitats. According to MEPRD (2014), the traditional management of grasslands (e.g. grazing, mowing) in Latvia has been significantly reduced, and this in turn influences plant diversity.

Our results are in line with the findings of Signorini et al. (2009) who also noted the dependency of local communities on very common species. In addition, Signorini et al. (2009) used an emic approach while discussing the distribution of taxa. Although most of the apophytes named in our study are widely distributed in the country this does not guarantee that the resource is inexhaustible and attainable by lay people. However, several apophyte taxa were reported by the interviewees as disappeared or not found nearby. This is particularly alarming in terms of food security for local communities as well as biodi- 


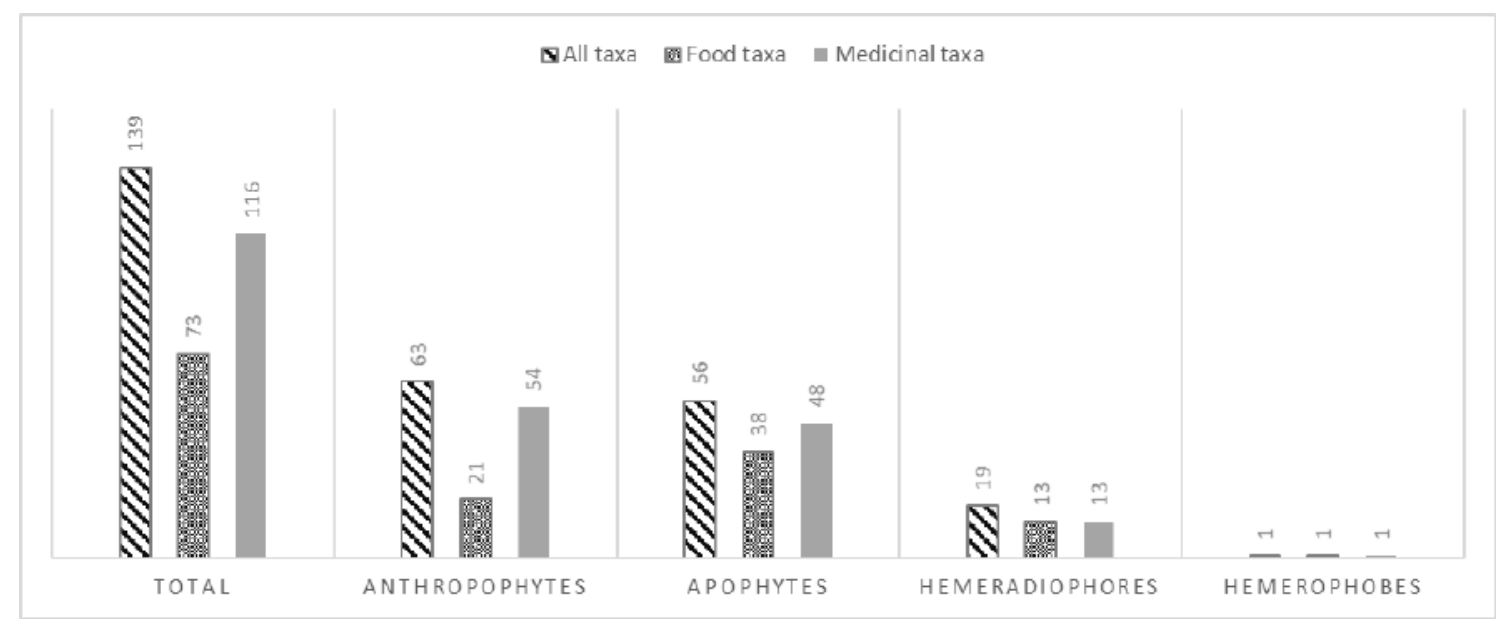

Figure 5. Division of the number of taxa named by interviewees for each category of sensitivity to human impact.

versity at large (see Gaston 2011). The perception of common might be dangerous, especially in situations where profit from wild collection is involved (see, for example, Sheldon et al. 1997). Recent studies have noted that "society increasingly focuses on managing nature for the services it provides people rather than for the existence of particular species" (Dee et al. 2017). Following this approach, our results suggest that common species support the needs of local communities by providing provisioning ecosystem services.

The high dependency on common or fairly common taxa causes us to contest the safety of their use. Questions concerning herbicides, infrastructure, rural-to-urban migration and land-grabbing have yet to be understood regarding the availability of so-called common taxa for collecting in Latvia. These and additional questions have been addressed by Marouf et al. (2015) while discussing the declining practice of wild plant foraging in Lebanon. As noted by Gaston (2010), common species lie at the centre of numerous pressures associated with biodiversity loss.

Similar results have been provided by other studies emphasising the use of nearby taxa (Sõukand and Kalle 2011) or disturbed habitats (Signorini et al. 2009; Voeks 2018) for medicinal use. To add, the difference between the division of synanthropic categories among medicinal and food uses may be linked to the constantly changing need for various medicinal taxa, and thus it is easier for people to operate within the better-known environment. However, the diversity of uses is greater for apophytes, even though there are fewer taxa in comparison to anthropophytes. This demonstrates that the specific, main repertoire of taxa is heavily exploited, a phenomenon also recorded in neighbouring Belarus, where only a few wild taxa had diverse uses in several domains (Sõukand et al. 2017).
While looking at past used taxa, we would have expected to observe more past uses linked with hemeradiophores, as indicated in the case study of Estonia (see Sõukand and Kalle 2011). However, this turned out not to be the case and a few hemeradiophores were mentioned only as a past use, most likely because the past for our interviewees is not so distant as the past in the above-mentioned article, and by the time our interviewees were born the shift towards more anthropophylic taxa had already occurred. Here we would like to add the point stressed by Albuquerque et al. (2015): "one must consider that the relationship of resource use to resource availability is a dynamic one and can lead to the decreased use of certain species as the environmental supply decreases" (p. 134). Thus, we stress the need to introduce a case-by-case approach by looking at the number or diversity of uses while discussing plant sensitivity to human activities. The study by Kala (2010) provides a case where use value and additional parameters (e.g. mode of harvest, rarity, endemism) are taken into account in order to prioritize conservation activities. Through this, we would like to stress the importance of the emic, or inside, viewpoint when discussing the importance of human-plant relationships. Ethnobotanical methods can help in this regard by providing qualitative data from the plant users themselves. Furthermore, people may provide both temporal (past vs current) and spatial dimensions with a particular focus on the local context. While the co-production of knowledge might be challenging on some level, it is highly prized by numerous scholars (Raven 2018; Norström et al. 2020; Rodrigues 2020). To add, Albuquerque et al. (2019a) study emphasises the positive benefit of integrating people's knowledge and needs in conservation activities. The OECD (2019) report notes that Latvia exhibits limited progress in regard to Aichi Biodiver- 


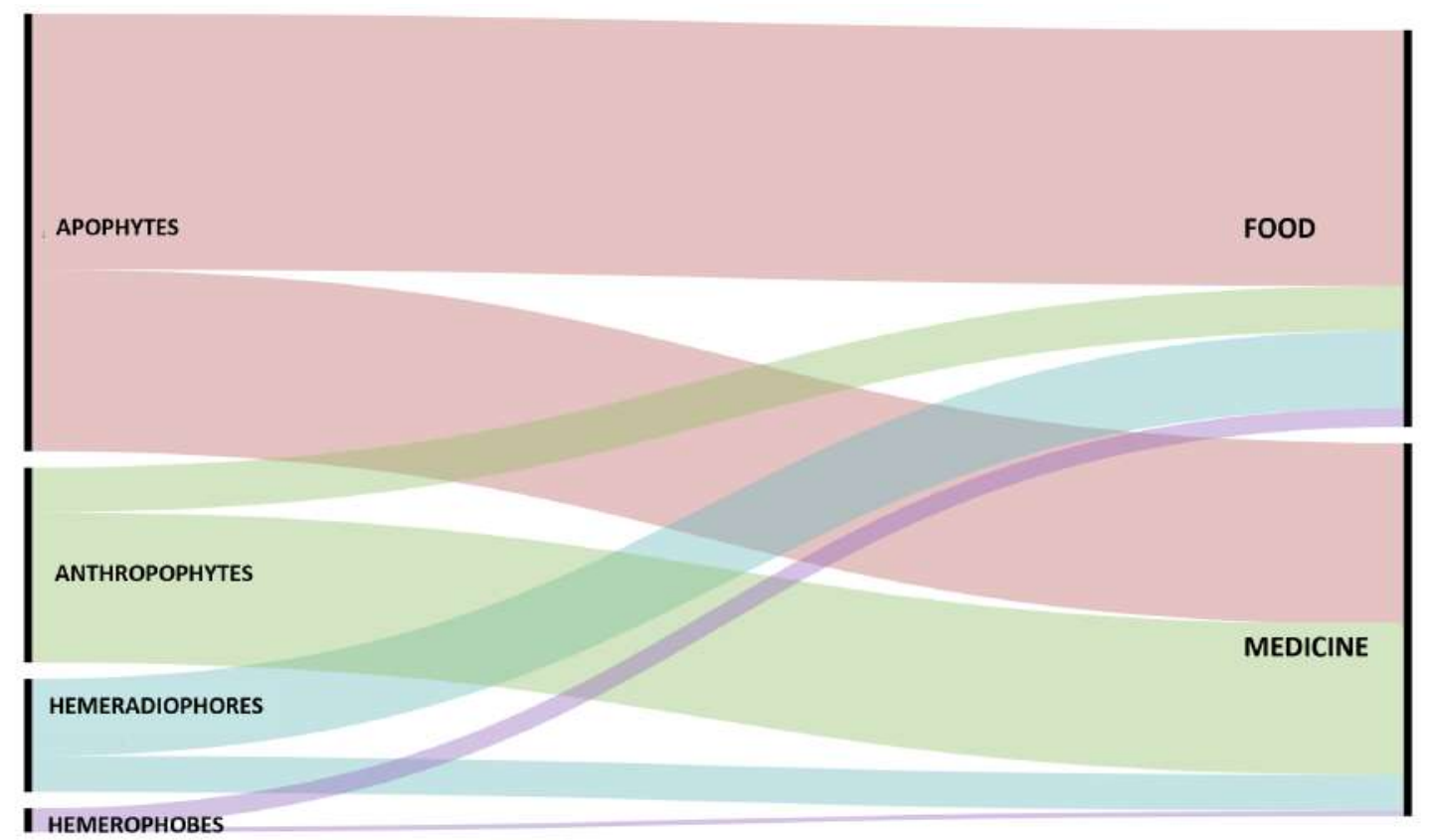

Figure 6. Division of DUR from the ethnobotanical dataset of the study area among medicinal and food uses for each of the four categories of sensitivity to human impact.

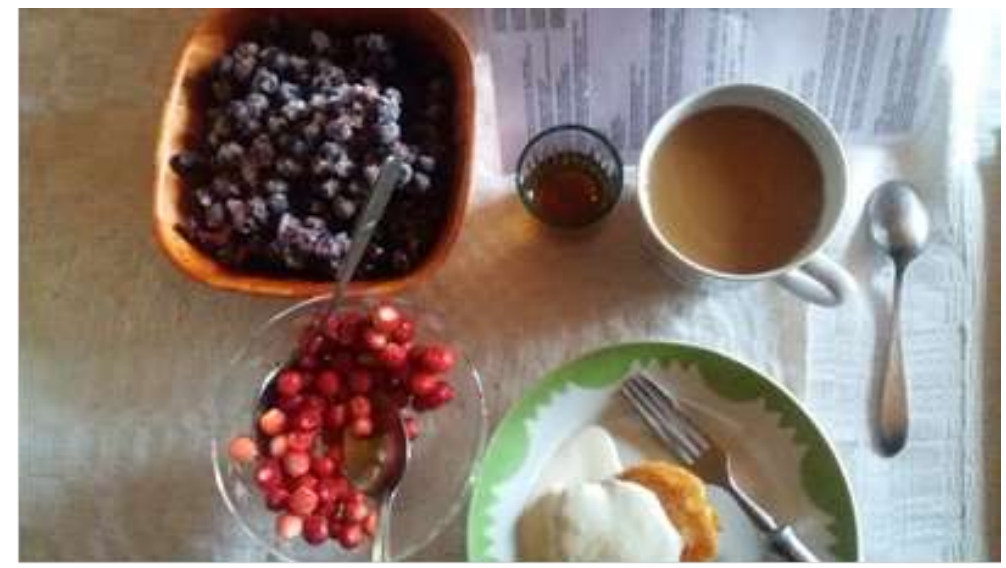

Figure 7. Berries (Vaccinium myrtillus \& Fragaria vesca) served by the interviewee. Credit: BP.

sity targets (CBD 2010) including the one linked to traditional knowledge across indigenous peoples and local communities. In this respect, ethnobotany may provide a valuable source of data regarding the customs of biological resource use of local communities (e.g. Prance 2007; Quave and Pieroni 2015). In support of this, the Constitution of the Republic of Latvia (1922) set the task for the State to safeguard the surrounding environment with the following declaration: "the State shall protect the right of everyone to live in a benevolent environment by providing information about environmental conditions and by promoting the preservation and improvement of the environment". We follow the rule of thumb given by Howard
(1997) which emphasises the general idea of people's behaviour towards environment protection as you protect what you value and care for (in Nisbet and Zelenski 2013).

\section{CONCLUSIONS}

Our study provides empirical evidence regarding local community dependency on common synanthropic taxa. Even though the study is case based and restricted to only one geographic area, we stress the importance of the findings regarding the relevance of ethnobotanical data while discussing local nature resource management strategies. The study 


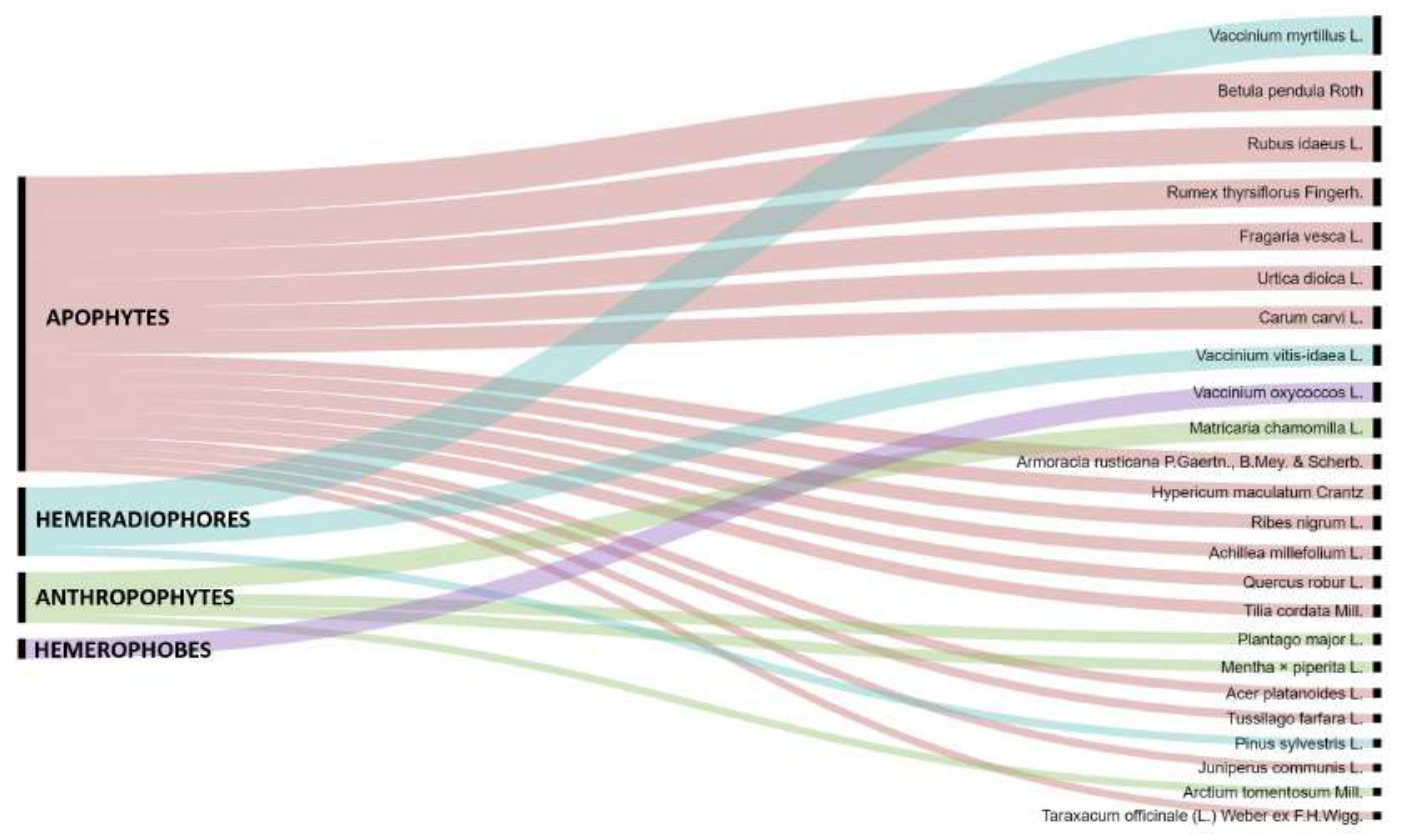

Figure 8. Division of the four categories of sensitivity to human impact based on DUR $>20$ among all taxa as provided by interviewees.

indicated high human dependency on taxa which, in turn, depend on human activity and are widely distributed across the country, which therefore calls attention to the current management strategies for these taxa. The study also provides grounds for further research on investigating possible management actions to safeguard common species before they become rare. Additionally, we would like to emphasize the importance of involving local communities, through various means including ethnobotanical studies, while discussing possible management strategies considering common species.

\section{ACKNOWLEDGEMENT}

We are grateful to the local people from the Latgale region who shared their local ecological knowledge and practices as the study would not have been possible without their contribution. We also thank the team from the Institute for Environmental Solutions and especially Rūta Abaja, Agris Brauns, Inga Holsta, Signe Krūzkopa. We would also like to thank Andrea Pieroni and Māris Kļavinsš for consultation at the final stage of manuscript preparation and Solvita Rūsiņa and Ieva Rūrāne for assistance with identification of relevant literature concerning Latvian flora. And we also thank the reviewers for the valuable reference sources. The research was supported by the Institute for Environmental Solutions and European Research Council under the European Union's Hori- zon 2020 research and innovation programme (grant agreement No 714874). Part of the language editing costs was covered by the University of Latvia.

\section{DATA AVAILABILITY}

The data that support the findings of this study are available from the corresponding author upon reasonable request.

\section{CONFLICT OF INTEREST}

The authors have no conflicts of interest to declare.

\section{CONTRIBUTION STATEMENT}

Conceived of the presented idea: BP, RK, RS

Carried out the experiment: BP, RS, RK, AS, IM

Carried out the data analysis: BP, RS

Wrote the first draft of the manuscript: BP, RS, RK, GB

Review and final write of the manuscript: BP, RS, RK, AS, IM, GB

Supervision: RS, RK 


\section{REFERENCES}

AiLab (n.d.) Latviešu folklora.

http://valoda.ailab.lv/folklora Accessed 23 april 2020 .

Albuquerque UP (2008) The Role of Ethnobotany and Environmental Perception in the Conservation of Atlantic Forest Fragments in Northeastern Brazil. Bioremediation, Biodiversity and Bioavailability 2(1): 27-34.

Albuquerque UP, Soldati GT, Ramos MA, de Melo JG, de Medeiros PM, Nascimento ALB, Ferreira Júnior WS (2015) The Influence of the Environment on Natural Resource Use: Evidence of Apparency. In: Albuquerque U, De Medeiros P, Casas A (eds) Evolutionary Ethnobiology. Springer, Cham. doi: 10.1007/978-3-319-19917-7_10.

Albuquerque UP, Nascimento ALB, Soldati GT, Feitosa IS, Campos JLA, Hurrell JA, Hanazaki N, Medeiros PM, Silvia RRV, Ludwinsky RH, Ferreira Júnior WS, Reyes-García V (2019) Ten important questions/issues for ethnobotanical research. Acta Botanica Brasilica. doi: 10.1590/0102$33062018 a b b 0331$.

Albuquerque UP, Nascimento ALBD, Chaves LS, Feitosa IS, Moura JMB, Gonçalves PHS, Silva RHD, Silva TCD, Ferreira Júnior WS, de Lima Araújo E (2019a) How to partner with people in ecological research: Challenges and prospects. Perspectives in Ecology and Conservation. doi: 10.1016/j.pecon.2019.11.004.

Albuquerque UP, Gonçalves PHS, Ferreira Júnior WS, Chaves LS, Oliveira RCS, da Silva TLL, Santos GC, Araújo EL (2018) Humans as niche constructors: revisiting the concept of chronic anthropogenic disturbances in ecology. Perspectives in Ecology and Conservation doi: 10.1016/j.pecon.2017.08.006.

Andrušaitis G (2003) Latvijas Sarkanā grāmata. 3. sējums. Vaskulārie augi. Rīga: Latvijas Universitātes Bioloǵijas institūts, pp. 691.

Auniņš A (2013) European Union Protected Habitats in Latvia. Interpretation Manual. ROKASGR_biotopi_EN.pdf. Accessed 23 april 2020.

Aswani S, Lemahieu A, Sauer WHH (2018) Global trends of local ecological knowledge and future implications. PLoS ONE. doi: 10.1371/journal.pone.0195440.

Baroniņa (2016) Eiropas Savien̄̄bas aizsargājamos biotopus raksturojošas augu sugas Lativjā II Zālāji. Eiropas Savienības aizsargājamos biotopus raksturojošas augu sugas Lativjā II Zālāji. Accessed
23 april 2020.

Beltrán-Rodríguez L, Ortiz-Sánchez A, Mariano NA, Maldonado-Almanza B, Reyes-García V (2014) Factors affecting ethnobotanical knowledge in a mestizo community of the Sierra de Huautla Biosphere Reserve, Mexico. Journal of Ethnobiology and Ethnomedicine doi: 10.1186/1746-4269-1014.

Bharucha Z, Pretty J (2010) The roles and values of wild foods in agricultural systems. Philosophical Transactions of the Royal Society B: Biological Sciences. doi: 10.1098/rstb.2010.0123.

Bignal EM, McCracken DI (1996) Low-Intensity Farming Systems in the Conservation of the Countryside. Journal of Applied Ecology doi: $10.2307 / 2404973$.

Brown A, Badura M, King G, Gos K, Cerina A, Kalnina L, Pluskowski A (2017) Plant macrofossil, pollen and invertebrate analysis of a mid-14th century cesspit from medieval Riga, Latvia (the eastern Baltic): Taphonomy and indicators of human diet. Journal of Archaeological Science: Reports. doi: 10.1016/j.jasrep.2017.01.016.

Bussmann RW (2002) Ethnobotany and biodiversity conservation. In: Ambasht RS, Ambasht NK (eds) Modern Trends in Applied Terrestrial Ecology. Springer, Boston, MA. doi: 10.1007/978-1-4615-02234_18.

Carter NH, Shrestha BK, Karki JB, Pradhan NMB, Liu J (2012) Coexistence between wildlife and humans at fine spatial scales. PNAS. doi: 10.1073/pnas.1210490109.

Cabinet of Minister No 396 (2000) Noteikumi par ippaši aizsargājamo sugu un ierobežoti izmantojamo īpaši aizsargājamo sugu sarakstu. https://likumi.lv/ta/id/12821-noteikumi-par-ipasiaizsargajamo-sugu-un-ierobezoti-izmantojamo-ipasiaizsargajamo-sugu-sarakstu. Accessed 23 april 2020.

CBD (Convention on Biological Diversity) (2010) Convention on Biological Diversity. https://www.cbd.int/doc/decisions/cop-10/cop-10dec-02-en.pdf. Accessed 23 april 2020.

Cunningham AB (2001) Applied Ethnobotany People, Wild Plant Use and Conservation. London: Earthscan.

Dabas dati (2020) Dabas dati. Dabas dati. Accessed 23 april 2020.

Dainu skapis (n.d.) Krišjāņa Barona Dainu skapis. http://dainuskapis.lv/katalogs. Accessed 23 april 2020. 
Dagdas novada pašvaldība (2018) Dagdas novada pašvaldības Publiskais pārskats par 2017.gadu. DNPPP-2017.pdf. Accessed 26 march 2020.

Dee LE, De Lara M,Costello C, Gaines SD (2017) To what extent can ecosystem services motivate protecting biodiversity? Ecology letters doi: 10.1111/ele.12790.

DNAP (2012) Dagdas novada attīstības programma 2013-2019, Dagdas novads. Dagdas Novada Attistibas Programa-01.pdf. Accessed 23 April 2020.

Evarte-Bundere G, Evarts-Bunders P, Lakša D, Nitcis M (2014) Inventory of Green Spaces and Woody Plants in the Urban Landscape of Rēzekne. Acta Biologica Universitatis Daugavpiliensis 14 (2): 123-136.

Fantinato E, Del Vecchio S, Giovanetti M, Acosta, ATR, Buffa G (2018) New insights into plants co-existence in species-rich communities: The pollination interaction perspective. Journal of Vegetation Science doi: 10.1111/jvs.12592.

FAO (2019) Biodiversity for food security Biodiversity for food security Biodiversity for food security. http://www.fao.org/3/CA3129EN/CA3129EN.pdf. Accessed 18 october 2020.

Frimpong EA (2018) A case for conserving common species. PLOS Biology. doi: 10.1371/journal.pbio. 2004261.

Gaston KJ (2008) Biodiversity and extinction: the importance of being common. Progress in Physical Geography. doi: 10.1177/0309133308089499.

Gaston KJ (2010) Ecology. Valuing common species. Science. doi: 10.1126/science.1182818.

Gaston (2011) Common Ecology. BioScience. doi: 10.1525/bio.2011.61.5.4.

Gavrilova Ģ, Šulcs V (1999) Latvijas vaskulāro augu flora. Taksonu saraksts.

Gavrilova G and Šulcs V (2005) Latvijas vaskulāro augu flora taksonu saraksts. saraksts.6.pdf Accessed 23 April 2020

Halada L, Evans D, Romão C, Petersen JE (2011) Which habitats of European importance depend on agricultural practices? Biodiversity and Conservation. doi: 10.1007/s10531-011-9989-z.

Hanazaki N, Herbst, DF, Marques, MS, Vandebroek I (2013) Evidence of the shifting baseline syndrome in ethnobotanical research. Journal of
Ethnobiology and Ethnomedicine. doi: 10.1186/17464269-9-75.

Heneidy S, Halmy MWA, Bidak L (2017) The ethnobotanical importance and conservation value of native plants in eastern Arabian Peninsula. Feddes Repertorium. doi: $10.1002 /$ fedr.201600024.

Heywood VH (2019) Conserving plants within and beyond protected areas - still problematic and future uncertain. Plant Divers doi: 10.1016/j.pld.2018.10.001.

Hunter D, Borelli T, Beltrame DMO, Oliveira CNS, Coradin L, Wasike VW, Wasilwa L, Mwai J, Manjella A, Samarasinghe GWL, Madhujith T, Nadeeshani HVH, Tan A, Ay ST, Güzelsoy N, Lauridsen N, Gee E, Tartanac F (2019) The potential of neglected and underutilized species for improving diets and nutrition. Planta. doi: $10.1007 / \mathrm{s} 004250190031694$.

ISE (International Society of Ethnobiology) (2006) ISE Code of Ethics. ISE-COE-Eng-rev24Nov08.pdf. Accessed 1 july 2017.

Kala CP (2010) Ethnobotanical and Ecological Approaches for Conservation of Medicinal and Aromatic Plants. Acta horticulturae doi: 10.17660/ActaHortic.2010.860.1.

Khoury KC, Amariles D, Soto JS, Diaz MV, Sotelo S, Sosa CS, Ramírez-Villegas J, Achicanoy HA, Velásquez-Tibatá J, Guarino L, León B, NavarroRacines C, Castañeda-Álvarez NP, Dempewolf H, Wiersema JH, Jarvis A (2019) Comprehensiveness of conservation of useful wild plants: An operational indicator for biodiversity and sustainable development targets. Ecological Indicators. doi: 10.1016/j.ecolind.2018.11.016.

Kukk (1999) Eesti taimestik [Vascular plant flora of Estonia]. http://www.zbi.ee/ tomkukk/nimestik. Accessed 1 March 2020.

Ksenzhek OS and Volkov AG (eds) (1998) Chapter 15 - Humans and Plants. In: Ksenzhek OS and Volkov AG (eds) Plant Energetics. Elsevier Inc. doi: 10.1016/B978-012427350-4/50016-9.

Laiviņš M, Zundāne A (1989) Latvijas ziedaugu un paparžaugu datu katalogs. Sinantropie elementi. ZRA "Silava", Salaspils. pp. 40.

Maffi L, \& Dilts O (2014) An Introduction to Biocultural Diversity. Biocultural Diversity Toolkit (Vol. 1, p. 44). http://terralingua.org/wpcontent/uploads/2015/07/tk_1_Primer.pdf Accessed 23 April 2020

Marouf M, Batal M, Moledor S, Talhouk SN (2015) 
Exploring the Practice of Traditional Wild Plant Collection in Lebanon. Food, Culture \&6 Society. doi: 10.1080/15528014.2015.1043103.

MEPRD (2014) $\boldsymbol{5}^{\text {th }}$ National Report to the Convention on Biological Diversity. www.cbd.int/doc/world/lv/lv-nr-05-en.pdf. Accessed 23 April 2020.

Millennium Ecosystem Assessment (2005) Ecosystems and Human Well-being: Synthesis. Island Press, Washington, DC.

Mulder MB and Coppolillo P (2005) Chapter 7 The Bigger Picture. In: Monique Borgerhoff M, Coppolillo P (eds) Conservation: Linking Ecology, Economics, and Culture. Princeton University Press, Princeton; Oxford, pp. 27-52.

Mora C, Sale P (2011) Ongoing global biodiversity loss and the need to move beyond protected areas: A review of the technical and practical shortcomings of protected areas on land and sea. Marine Ecology Progress Series. doi: 10.3354/meps09214.

Nikodemus O, Kļaviņš M, Krišjāne Z, Zelčs V (2018) Latvija: zeme, daba, tauta, valsts. Latvijas Universitātes Akadēmiskais apgāds, Rīga.

Nisbet EK and Zelenski JM (2013) The NR-6: a new brief measure of nature relatedness. Frontiers in psychology. doi: 10.3389/fpsyg.2013.00813.

Norström AV, Cvitanovic C, Löf MF, West S, Wyborn C, Balvanera P, Bednarek AT, Bennett EM, Biggs R, Bremond A, Campbell BM, Canadell JG, Carpenter SR, Folke C, Fulton EA, Gaffney O, Gelcich S, Jouffray JB, Leach M, Tissier MLe, Martín-López B, Louder E, Loutre MF, Meadow AM, Nagendra H, Payne D, Peterson GD, Reyers B, Scholes R, Speranza CI, Spierenburg M, Stafford-Smith M, Tengö M, van der Hel S, van Putten I, Österblom H (2020) Principles for knowledge co-production in sustainability research. Nature Sustainability doi: 10.1038/s41893-019-0448-2.

OECD (2019) OECD Environmental Performance Reviews: Latvia 2019. https://www.oecd-ilibrary.org/sites/9c1ffde5en/index.html?itemId $=/$ content $/$ component $/ 9 \mathrm{c} 1 \mathrm{ffde} 5$ en. Accessed 23 april 2020.

Ouédraogo I, Nacoulma BMI, Hahn K, Thiombiano A (2014) Assessing ecosystem services based on indigenous knowledge in south-eastern Burkina Faso (West Africa). International Journal of Biodiversity Science, Ecosystem Services \& Management. doi: 10.1080/21513732.2014.950980.
Poncet A, Vogl CR, Weckerle CS (2015) Folkbotanical classification: Morphological, ecological and utilitarian characterization of plants in the Napf region, Switzerland. Journal of Ethnobiology and Ethnomedicine. doi: 10.1186/1746-4269-1113.

Prance GT (2007) Ethnobotany, the science of survival: a declaration from Kaua'i. Economic Botany doi: 10.1007/BF02862367.

Priedītis (n.d.) Enciklopēdija "Latvijas Daba". www.latvijasdaba.lv Accessed 23 april 2020.

Priedītis N (2014) Latvijas augi. Rīga: Gandrs.

Prūse B, Simanova A, Mežaka I, Kalle R, Prakofjewa J, Pieroni A, Holsta I, Krūzkopa S, Sõukand R (under revision) Language and belonging: wild food practices in Latgale, Latvia. Environment, Development and Sustainability.

Quave C, Pieroni A (2015) A reservoir of ethnobotanical knowledge informs resilient food security and health strategies in the Balkans. Nature Plants. doi: 10.1038/nplants.2014.21.

Raven PH (2018) Saving plants, saving ourselves. Plants, People, Planet doi: 10.1002/ppp3.3.

Rimkus E, Briede A, Jaagus J, Stonevicius E, Kilpys J, Viru B (2018) Snow-cover regime in Lithuania, Latvia and Estonia and its relationship to climatic and geographical factors in 1961-2015. Boreal Environment Research. 23: 193-208.

Rodrigues E, Cassas F, Conde BE, da Cruz C, Barretto EHP, dos Santos G, Figueira GM, Passero LFD, dos Santos MA, Gomes MAS, Matta P, Yazbek P, Garcia RJF, Braga S, Aragaki S, Honda S, Sauini T, da Fonseca-Kruel VS, Ticktin T (2020) Participatory ethnobotany and conservation: a methodological case study conducted with quilombola communities in Brazil's Atlantic Forest. Journal of Ethnobiology and Ethnomedicine. doi: 10.1186/s13002-019-0352-x.

Rūsinga S, Auniņš A, Sprunggis V (2005) Chapter 18. 6510 Lowland hay meadows. In: Rūsina S (ed). 3 ed. Protected Habitat Management Guidelines for Latvia. Semi-natural Grasslands. Nature Conservation Agency, Sigulda, Habitat Management Guidelines for Latvia. pp. 218-227.

Schultes RE (1994) The Importance of Ethnobotany in Environmental Conservation. American Journal of Economics and Sociology. doi: 10.1111/j.1536-7150.1994.tb02586.x.

Sheldon JW, Balick MJ, Laird SA (1997) Medicinal Plants: Can Utilization and Conservation Coexist? Advances in Economic Botany. 12 ed. Series 
Editor Charles Peters. New York: New York Botanical Garden.

Shrestha S and Medley KE (2017) Integrating Ecological and Ethnobotanical Knowledge to Promote Collaborative Conservation Planning in the Nepal Himalaya. Mountain Research and Development. doi: 10.1659/MRD-JOURNAL-D-1500081.1.

Signorini MA, Piredda M, Bruschi P (2009) Plants and traditional knowledge: An ethnobotanical investigation on Monte Ortobene (Nuoro, Sardinia). Journal of Ethnobiology and Ethnomedicine. doi: 10.1186/1746-4269-5-6.

Sile I, Romane E, Reinsone S, Maurina B, Tirzite D, Dambrova M (2019) Medicinal plants and their uses recorded in the Archives of Latvian Folklore from the 19th century. Journal of Ethnopharmacology. doi: 10.1016/j.jep.2019.112378.

Simanova A, Prūse B, Kalle R, Kochalski, S, Prakofjewa J, Mežaka I, Pieroni A, Soukand R (2020) Medicinal plant use at the beginning of the $21^{\text {st }}$ century among the religious minority in Latgale Region, Latvia. Ethnobotany Research 8 Applications. doi: 10.32859/era.20.21.1-31.

Smith MD, Knapp AK (2003) Dominant species maintain ecosystem function with non-random species loss. Ecology Letters doi: 10.1046/j.14610248.2003.00454.x.

Suomela JA, Vajanto K, Räisänen R (2018) Seeking Nettle Textiles - Utilizing a Combination of Microscopic Methods for Fibre Identification. Studies in Conservation. doi: 10.1080/00393630.2017.1410956.

Suško U and Evarts-Bunders P (2010) The history of botanical investigations in South-east Latvia. Latvijas Veǵetācija 21: 101-125.

Stepp JR, Moerman DE (2001) The importance of weeds in ethnopharmacology. Journal of Ethnopharmacology. doi: 10.1016/S03788741(00)00385-8.

Svilāns A, Roze D, Lukaševičs V (2012) Plants as a sign of Latgalian identity in cultural landscape, writing and stories. Via Latgalica doi: 10.17770/latg2012.4.1692.

Sõukand R and Kalle R (2012) Personal and shared: The reach of different herbal landscapes. Estonian Journal of Ecology. doi: 10.3176/eco.2012.1.04

Sõukand R, Hrynevich Y, Vasilyeva I, Prakofjewa J, Vnukovich Y, Paciupa J, Hlushko A, Knureva Y, Litvinava Y, Vyskvarka S, Silivonchyk H, Paulava A,
Kõiva M, Kalle R (2017) Multi-functionality of the few: Current and past uses of wild plants for food and healing in Liuban region, Belarus. Journal of Ethnobiology and Ethnomedicine. doi: 10.1186/s13002-017-0139-x.

Sõukand R, Kalle R (2011) Change in medical plant use in Estonian ethnomedicine: a historical comparison between 1888 and 1994. Journal of Ethnopharmacology. doi: 10.1016/j.jep.2011.02.030.

Tabaka L, Gavrilova G, Fatare I (1988) Flora of vascular plants of Latvian SSR.

Tang R, Gavin MC (2016) A classification of threats to traditional ecological knowledge and conservation responses. Conservation and Society. doi: 10.4103/0972-4923.182799.

The Shenzhen Declaration (2017) The Shenzhen declaration on plant sciences-Uniting plant sciences and society to build a green, sustainable Earth. Plants, People, Planet. doi: 10.1002/ppp3.13.

The Constitution of the Republic of Latvia (1922) The Constitution of the Republic of Latvia. https://likumi.lv/ta/en/en/id/57980-theconstitution-of-the-republic-of-latvia. Accessed 23 april 2020.

Vila-Ruiz CP, Meléndez-Ackerman E, SantiagoBartolomei R, Garcia-Montiel D, Lastra L, Figuerola CE, Fumero-Caban J (2014) Plant species richness and abundance in residential yards across a tropical watershed: implications for urban sustainability. Ecology and Society. doi: 10.5751/ES06164-190322.

Voeks RA (2018) The Ethnobotany of Eden: Rethinking the Jungle Medicine Narrative. The University of Chicago Press, Chicago, IL, U.S.A. pp. 328.

Western D, Waithaka J, Kamanga J (2015) Finding Space for Wildlife beyond National Parks and Reducing Conflict through Community-based Conservation: the Kenya Experience. Parks. doi: 10.2305/IUCN.CH.2014.PARKS-21-1DW.en.

Winfree R, Fox JW, Williams NM, Reilly JR, Cariveau DP (2015) Abundance of common species, not species richness, drives delivery of a real-world ecosystem service. Ecology Letters. doi: $10.1111 /$ ele.12424.

Zimdahl RL (2018) CHAPTER 4 - Ethnobotany: Uses of Weeds. In: Zimdahl RL (ed) Fundamentals of Weed Science. Elsevier Inc. pp.464 
Received: 5 April 2020

Accepted: 23 November 2020

Available: 10 December 2020 


\section{Additional Files}

Add File 1. Abbreviations: '-' -lack of information in the source used; 'W' - wild; 'LRB' - Latvian Red Book; 'C' - cultivated; 'P' - purchased; 'c' common; 'fc' - fairly common; 'fr' - fairly rare; 'r' - rare; 'vr' - very rare; 1 - along roadsides/railways; 2 - gravel, loam, sand, dolomite, dunes, nutrient poor habitats; 3 - human-influenced environments, nutrient-rich habitats; 4 - on fallow lands; 5 - in pastures; 6 - in various forest habitats including pine forests, in shrubs; 7 - across various habitats, open, dry, other; 8 - in various meadows (excluding wet habitats), forest edges, hillslopes; 9 - wasty places; 10 - wet and swampy habitats, bogs, wet forests. \$ - taxa considered as hemeradiophores by Kukk (1999), but which for calculations we considered apophytes due to their actual use as cultivars or semi-wild status, as their use requires extended human attention; *adopted from Priedītis (2014); blank no information in the reference sources.

\begin{tabular}{|c|c|c|c|c|c|c|c|c|c|}
\hline Latin name & $\begin{array}{l}\text { Status (Gavrilova } \\
\text { and Šulcs 2005) }\end{array}$ & $\begin{array}{l}\text { Occurrence } \\
\text { in the wild } \\
\text { (Gavrilova } \\
\text { and Šulcs } \\
2005 ; \\
\text { Priedītis, } \\
2014 \text { ) }\end{array}$ & $\begin{array}{l}\text { Cultivated } \\
\text { or wild } \\
\text { (authors' } \\
\text { notes) }\end{array}$ & $\begin{array}{l}\text { Habitats } \\
\text { (Priedītis } \\
2014 \text { ) }\end{array}$ & $\begin{array}{l}\text { Category of } \\
\text { sensitivity to } \\
\text { human impact } \\
(\text { Kukk 1999) }\end{array}$ & $\begin{array}{l}\text { Food } \\
\text { DUR }\end{array}$ & - & $\begin{array}{l}\text { Medicine } \\
\text { - DUR }\end{array}$ & $\begin{array}{l}\text { Total } \\
\text { DUR }\end{array}$ \\
\hline Acer platanoides L., Sapindaceae & & $\mathrm{c}$ & $\mathrm{W}$ & 6,3 & hemeradiophores $^{\$}$ & 23 & & 3 & 26 \\
\hline $\begin{array}{l}\text { Achillea millefolium L., Aster- } \\
\text { aceae }\end{array}$ & & $\mathrm{c}$ & $\mathrm{W}$ & $9,8,3,2,1$ & apophytes & 7 & & 29 & 36 \\
\hline Acorus calamus L., Acoraceae & & fc & W & 10 & anthropophytes & 3 & & 8 & 11 \\
\hline $\begin{array}{l}\text { Aegopodium podagraria L., Api- } \\
\text { aceae }\end{array}$ & & $\mathrm{c}$ & $\mathrm{W}$ & 7 & apophytes & 3 & & & 3 \\
\hline $\begin{array}{l}\text { Aesculus hippocastanum L., } \\
\text { Sapindaceae }\end{array}$ & $\begin{array}{l}\text { cultivated plants } \\
\text { sometimes found } \\
\text { in disturbed areas, } \\
\text { along railways and } \\
\text { on abandoned land }\end{array}$ & fr & W & & anthropophytes & 1 & & 9 & 10 \\
\hline $\begin{array}{l}\text { Alchemilla vulgaris auct., } \\
\text { Rosaceae }\end{array}$ & & fc & $\mathrm{W}$ & 7 & apophytes & 4 & & 10 & 14 \\
\hline Allium cepa L., Amaryllidaceae & $\begin{array}{l}\text { cultivated plants } \\
\text { sometimes found } \\
\text { in disturbed areas, } \\
\text { along railways and } \\
\text { on abandoned land }\end{array}$ & & $\mathrm{C}$ & & anthropophytes & & & 10 & 10 \\
\hline
\end{tabular}




\begin{tabular}{|c|c|c|c|c|c|c|c|c|}
\hline $\begin{array}{l}\text { Allium sativum L., Amarylli- } \\
\text { daceae }\end{array}$ & $\begin{array}{l}\text { cultivated plants } \\
\text { sometimes found } \\
\text { in disturbed areas, } \\
\text { along railways and } \\
\text { on abandoned land }\end{array}$ & & $\mathrm{C}$ & & anthropophytes & & 15 & 15 \\
\hline $\begin{array}{l}\text { Allium schoenoprasum L., } \\
\text { Amaryllidaceae }\end{array}$ & & $\mathrm{r}$ & $\mathrm{W}(\mathrm{LRB})$ & $10,3,2$ & apophytes & 1 & & 1 \\
\hline $\begin{array}{l}\text { Allium ursinum L., Amarylli- } \\
\text { daceae }\end{array}$ & & fr & $\mathrm{W}(\mathrm{LRB})$ & 6 & hemeradiophores & 2 & & 2 \\
\hline $\begin{array}{l}\text { Alnus glutinosa (L.) Gaertn., Be- } \\
\text { tulaceae }\end{array}$ & & fc & $\mathrm{W}$ & 10,6 & hemeradiophores & 7 & & 7 \\
\hline $\begin{array}{l}\text { Alnus incana (L.) Moench, Be- } \\
\text { tulaceae }\end{array}$ & & $\mathrm{c}$ & $\mathrm{W}$ & $10,6,3$ & apophytes & 9 & 1 & 10 \\
\hline $\begin{array}{l}\text { Aloe arborescens Mill., Xanthor- } \\
\text { rhoeaceae }\end{array}$ & & & $\mathrm{C}$ & & anthropophytes & & 10 & 10 \\
\hline $\begin{array}{l}\text { Anethum graveolens L., Api- } \\
\text { aceae }\end{array}$ & $\begin{array}{l}\text { escaped cultivated } \\
\text { plants which infre- } \\
\text { quently naturalize }\end{array}$ & fr & $\mathrm{C}$ & 3 & anthropophytes & & 4 & 4 \\
\hline $\begin{array}{l}\text { Arctium tomentosum Mill., } \\
\text { Asteraceae }\end{array}$ & & $\mathrm{c}$ & $\mathrm{W}$ & $9,8,6,1$ & anthropophytes & & 21 & 21 \\
\hline $\begin{array}{l}\text { Arctostaphylos uva-ursi (L.) } \\
\text { Spreng., Ericaceae }\end{array}$ & & fr & $\mathrm{W}$ & 8,6 & hemeradiophores & & 4 & 4 \\
\hline $\begin{array}{l}\text { Armoracia rusticana P.Gaertn., } \\
\text { B.Mey. \& Scherb., Brassicaceae }\end{array}$ & $\begin{array}{l}\text { escaped plants } \\
\text { which commonly } \\
\text { naturalize }\end{array}$ & fc & $\mathrm{C} / \mathrm{W}$ & & apophytes & 33 & 6 & 39 \\
\hline $\begin{array}{l}\text { Aronia melanocarpa (Michx.) } \\
\text { Elliott, Rosaceae }\end{array}$ & $\begin{array}{l}\text { escaped cultivated } \\
\text { plants which infre- } \\
\text { quently naturalize }\end{array}$ & $\mathrm{r}$ & $\mathrm{C}$ & & anthropophytes & & 7 & 7 \\
\hline $\begin{array}{l}\text { Artemisia absinthium L., Aster- } \\
\text { aceae }\end{array}$ & $\begin{array}{l}\text { completely natural- } \\
\text { ized escaped culti- } \\
\text { vated species }\end{array}$ & fr & $\mathrm{W}$ & $9,4,1$ & apophytes & 3 & 8 & 11 \\
\hline $\begin{array}{l}\text { Artemisia vulgaris L., Aster- } \\
\text { aceae }\end{array}$ & & $\mathrm{c}$ & $\mathrm{W}$ & 7,3 & apophytes & & 3 & 3 \\
\hline $\begin{array}{l}\text { Atriplex patula L., Amaran- } \\
\text { thaceae }\end{array}$ & & fc & W & $9,3,1$ & anthropophytes & 2 & 2 & 4 \\
\hline
\end{tabular}


cultivated plants $r^{*}$ sometimes found in disturbed areas, along railways and on abandoned land

Berberis vulgaris L., Berberion abandoned land

daceae

Bergenia crassifolia (L.) Fritsch,

Saxifragaceae

Beta vulgaris L., Amaranthaceae

Beta vulgaris L., Amaranthaceae

Betula pendula Roth, Betula

pubescens Ehrh., Betulaceae

Bidens tripartita L., Asteraceae

Borago officinalis L., Boraginaceae

Brassica oleracea var. capitata f. alba DC., Brassicaceae

cultivated plants sometimes found

in disturbed areas,

along railways and

on abandoned land

escaped cultivated

plants which infre-

quently naturalize

cultivated plants

\section{fr}

c

c

W

W

$10,6,5$

apophytes

3

3

C

$9,3,1$

anthropophytes

1

anthropophytes

5

1

6

sometimes found

in disturbed areas,

along railways and

on abandoned land

Briza media L., Poaceae

Calendula officinalis L., Aster-

aceae

cultivated plants

$\begin{array}{llllll}\mathrm{c} & \mathrm{W} & 8,4,6 & \text { apophytes } & 1 & 1 \\ \mathrm{fr} * & \mathrm{C} & 9,3,1 & \text { anthropophytes } & 14 & 14\end{array}$

W

6,3

10

$9,3,1$

hemeradiophores $^{\$}$

45

apophytes

anthropophytes

4

anthropophytes

12

sometimes found

in disturbed areas,

along railways and

on abandoned land

Callisia fragrans (Lindl.) Wood-

son, Commelinaceae

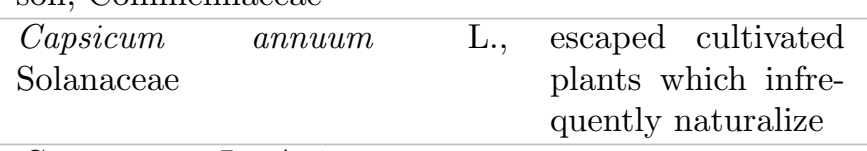

Carum carvi L., Apiaceae 


\begin{tabular}{|c|c|c|c|c|c|c|c|c|}
\hline $\begin{array}{l}\text { Chelidonium majus L., Papaver- } \\
\text { aceae }\end{array}$ & & $\mathrm{c}$ & W & $9,6,3$ & anthropophytes & & 7 & 7 \\
\hline $\begin{array}{l}\text { Chenopodium album L., Ama- } \\
\text { ranthaceae }\end{array}$ & & $\mathrm{c}$ & $\mathrm{W}$ & 3 & apophytes & 2 & & 2 \\
\hline $\begin{array}{l}\text { Cichorium intybus L., Aster- } \\
\text { aceae }\end{array}$ & & fr & $\mathrm{W}$ & $10,9,8,2,1$ & anthropophytes & 4 & & 4 \\
\hline $\begin{array}{l}\text { Cirsium heterophyllum (L.) Hill, } \\
\text { Asteraceae }\end{array}$ & & fc & W & 8,6 & apophytes & & 1 & 1 \\
\hline $\begin{array}{l}\text { Citrus limon (L.) Osbeck, Ru- } \\
\text { taceae }\end{array}$ & & & $\mathrm{P}$ & & anthropophytes & & 5 & 5 \\
\hline Corylus avellana L., Betulaceae & & $\mathrm{c}$ & $\mathrm{W}$ & $10,8,6$ & apophytes & 11 & 1 & 12 \\
\hline $\begin{array}{l}\text { Crassula ovata (Mill.) Druce, } \\
\text { Crassulaceae }\end{array}$ & & & $\mathrm{C}$ & & anthropophytes & & 4 & 4 \\
\hline $\begin{array}{l}\text { Crataegus rhipidophylla Gand., } \\
\text { Rosaceae }\end{array}$ & & fr & $\mathrm{W}$ & $10,8,6$ & hemeradiophores & 2 & 3 & 5 \\
\hline $\begin{array}{l}\text { Cucumis sativus L., Cucur- } \\
\text { bitaceae }\end{array}$ & $\begin{array}{l}\text { cultivated plants } \\
\text { sometimes found } \\
\text { in disturbed areas, } \\
\text { along railways and } \\
\text { on abandoned land }\end{array}$ & & $\mathrm{C}$ & & anthropophytes & & 1 & 1 \\
\hline Cyanus segetum Hill, Asteraceae & & $\mathrm{c}$ & W & $9,3,1$ & anthropophytes & & 5 & 5 \\
\hline $\begin{array}{l}\text { Daucus carota L. subsp. sativus } \\
\text { (Hoffm.) Arcang., Apiaceae }\end{array}$ & & fr & W & $10,8,2$ & anthropophytes & & 3 & 3 \\
\hline $\begin{array}{l}\text { Elaeagnus rhamnoides (L.) } \\
\text { A.Nelson, Elaeagnaceae }\end{array}$ & $\begin{array}{l}\text { escaped plants } \\
\text { which commonly } \\
\text { naturalize }\end{array}$ & fr & $\mathrm{C}$ & $9,2,1$ & anthropophytes & & 1 & 1 \\
\hline $\begin{array}{l}\text { Epilobium angustifolium L., On- } \\
\text { agraceae }\end{array}$ & & $\mathrm{c}$ & W & $9,8,3,1$ & apophytes & 4 & 10 & 14 \\
\hline $\begin{array}{l}\text { Equisetum arvense L., Equise- } \\
\text { taceae }\end{array}$ & & $\mathrm{c}$ & W & $8,4,1$ & apophytes & 1 & 2 & 3 \\
\hline Erigeron acris L., Asteraceae & & $\mathrm{c}$ & W & $9,8,4$ & apophytes & & 3 & 3 \\
\hline Ficus carica L., Moraceae & & & $\mathrm{C}$ & & anthropophytes & & 1 & 1 \\
\hline $\begin{array}{l}\text { Filipendula ulmaria (L.) } \\
\text { Maxim., Rosaceae }\end{array}$ & & $c^{*}$ & W & 7 & hemeradiophores & & 8 & 8 \\
\hline Fragaria vesca L., Rosaceae & & $\mathrm{c}$ & $\mathrm{W}$ & $8,6,4$ & apophytes & 74 & & 74 \\
\hline $\begin{array}{l}\text { Frangula alnus Mill., Rham- } \\
\text { naceae }\end{array}$ & & $\mathrm{c}$ & W & $10,8,6$ & hemeradiophores & 1 & & 1 \\
\hline
\end{tabular}


Helianthus tuberosus L., Asteraceae

escaped plants
which commonly
naturalize

Helichrysum arenarium

(L.) naturalize

Moench, Asteraceae

Heracleum sosnowskyi Manden.

Apiaceae

completely natural-

ized escaped culti-

vated species

Heracleum sphondylium subsp. sibiricum (L.) Simonk., Apiaceae

Humulus lupulus L.

Cannabaceae

Hypericum maculatum Crantz,

Hypericaceae

Juniperus communis L., Cupres-

saceae

Leonurus cardiaca L., Lamiaceae

Leucanthemum vulgare (Vaill.)

Lam., Asteraceae

Levisticum

officinale

W.D.J.Koch, Apiaceae

escaped cultivated

plants which infre-

quently naturalize

\begin{tabular}{|c|c|c|c|c|c|c|c|}
\hline $\begin{array}{lll}\text { Linum } & \text { usitatissimum } & \text { L., } \\
\text { Linaceae } & \end{array}$ & $\begin{array}{l}\text { cultivated plants } \\
\text { sometimes found } \\
\text { in disturbed areas, } \\
\text { along railways and } \\
\text { on abandoned land }\end{array}$ & $\mathrm{C}$ & 9,1 & anthropophytes & & 4 & 4 \\
\hline $\begin{array}{l}\text { Malus domestica } \\
\text { Rosaceae }\end{array}$ & $\begin{array}{l}\text { completely natural- fr } \\
\text { ized escaped culti- } \\
\text { vated species }\end{array}$ & $\mathrm{W} / \mathrm{C}$ & & anthropophytes & 10 & & 10 \\
\hline $\begin{array}{l}\text { Matricaria chamomilla L., } \\
\text { Asteraceae }\end{array}$ & $\begin{array}{l}\text { escaped plants fr } \\
\text { which commonly } \\
\text { naturalize }\end{array}$ & $\mathrm{C}$ & 9,3 & anthropophytes & 13 & 41 & 54 \\
\hline
\end{tabular}

\begin{tabular}{|c|c|c|c|c|}
\hline fr & 8,6 & hemeradiophores & 1 & 1 \\
\hline fc & W & anthropophytes & 1 & 1 \\
\hline
\end{tabular}

\begin{tabular}{|c|c|c|c|c|c|c|}
\hline fc & $\mathrm{W}$ & $9,8,6$ & apophytes & 1 & & 1 \\
\hline fc & W & 10 & hemeradiophores & 2 & 3 & 5 \\
\hline
\end{tabular}

\begin{tabular}{|c|c|c|c|c|c|c|}
\hline fc & $\mathrm{W}$ & & apophytes & 22 & 17 & 39 \\
\hline fc & $\mathrm{W}$ & $6,5,2$ & apophytes & 14 & 8 & 22 \\
\hline $\mathrm{vr}$ & $\mathrm{C}$ & $9,3,1$ & anthropophytes & & 7 & 7 \\
\hline $\mathrm{c}$ & $\mathrm{W}$ & $8,5,4,3$ & apophytes & & 2 & 2 \\
\hline
\end{tabular}

fr

C

anthropophytes

in disturbed areas,

along railways and

Malus domestica Borkh., completely natural-

ized escaped culti-

Matricaria

naturalize 


\begin{tabular}{|c|c|c|c|c|c|c|c|c|}
\hline $\begin{array}{l}\text { Matricaria discoidea DC., Aster- } \\
\text { aceae }\end{array}$ & $\begin{array}{l}\text { adventitious species } \\
\text { in the Latvian flora } \\
- \text { ephemerophytes } \\
\text { and neophytes } \\
\text { (archeopytes are } \\
\text { viewed as indige- } \\
\text { nous species) }\end{array}$ & $\mathrm{fr}$ & $\mathrm{W}$ & 1 & anthropophytes & & 1 & 1 \\
\hline $\begin{array}{l}\text { Melampyrum nemorosum L., } \\
\text { Orobanchaceae }\end{array}$ & & fr & $\mathrm{W}$ & 8,6 & hemeradiophores & 1 & & 1 \\
\hline Melissa officinalis L., Lamiaceae & $\begin{array}{l}\text { escaped cultivated } \\
\text { plants which infre- } \\
\text { quently naturalize }\end{array}$ & $\mathrm{r}$ & $\mathrm{W}$ & & anthropophytes & & 1 & 1 \\
\hline $\begin{array}{l}\text { Mentha } \times \text { piperita L., Mentha } \\
\text { longifolia (L.) L., Lamiaceae }\end{array}$ & $\begin{array}{l}\text { escaped plants } \\
\text { which commonly } \\
\text { naturalize }\end{array}$ & fr & $\mathrm{C} / \mathrm{W}$ & 9,3 & anthropophytes & 14 & 15 & 29 \\
\hline Nepeta cataria L., Lamiaceae & $\begin{array}{l}\text { escaped plants } \\
\text { which commonly } \\
\text { naturalize }\end{array}$ & fr & $\mathrm{C} / \mathrm{W}$ & 9,1 & anthropophytes & & 4 & 4 \\
\hline $\begin{array}{l}\text { Origanum vulgare L., Origanum } \\
\text { vulgare }\end{array}$ & & fc & W & 8,1 & apophytes & 4 & 2 & 6 \\
\hline Oxalis acetosella L., Oxalidaceae & & $\mathrm{c}$ & $\mathrm{W}$ & 6 & hemeradiophores & 10 & & 10 \\
\hline $\begin{array}{l}\text { Oxalis corniculata L., Oxali- } \\
\text { daceae }\end{array}$ & $\begin{array}{l}\text { adventitious species } \\
\text { in the Latvian flora } \\
- \text { ephemerophytes } \\
\text { and neophytes } \\
\text { (archeopytes are } \\
\text { viewed as indige- } \\
\text { nous species) }\end{array}$ & $\mathrm{vr}$ & $\mathrm{W}$ & 9,3 & anthropophytes & 1 & & 1 \\
\hline $\begin{array}{l}\text { Paeonia lactiflora Pall., Paeoni- } \\
\text { aceae }\end{array}$ & & & $\mathrm{C}$ & & anthropophytes & & 6 & 6 \\
\hline $\begin{array}{l}\text { Papaver somniferum L., } \mathrm{Pa}- \\
\text { paveraceae }\end{array}$ & $\begin{array}{l}\text { escaped cultivated } \\
\text { plants which infre- } \\
\text { quently naturalize }\end{array}$ & $\mathrm{r}$ & $\mathrm{C}$ & $9,3,1$ & anthropophytes & & 1 & 1 \\
\hline $\begin{array}{l}\text { Pelargonium graveolens L'Hér, } \\
\text { Geraniaceae }\end{array}$ & & & $\mathrm{C}$ & & anthropophytes & & 20 & 20 \\
\hline $\begin{array}{l}\text { Petasites spurius (Retz.) Rchb., } \\
\text { Asteraceae }\end{array}$ & & fc & W & & hemeradiophores & & 1 & 1 \\
\hline $\begin{array}{l}\text { Phaseolus vulgaris L., Legumi- } \\
\text { nosae }\end{array}$ & & & $\mathrm{C}$ & 1 & anthropophytes & & 2 & 2 \\
\hline
\end{tabular}


Philadelphus coronarius L., Hy-

C

anthropophytes

2

1

3

drangeaceae

Phleum pratense L., Poaceae

Picea abies (L.) H.Karst. $8,5,6,3$ apophytes

hemeradiophores 1

Pinaceae

Pilosella officinarum Vaill.

c

6

Asteraceae

Pinus sylvestris L., Pinaceae

Piper nigrum L., Piperaceae

Plantago major L., Plantagi-

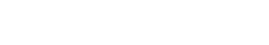

W

$\mathrm{W} \quad 8,2$

8,2

\author{
apophytes
}

2

$\begin{array}{ll}\text { W } & 2 \\ \text { P } & 10 \\ \text { W }\end{array}$

naceae

naceae

Polygala vulgaris L., Poly-

c $\quad$ W

2

10,3

hemeradiophores

$9,8,6,4$

anthropophytes

$9,4,3,2$

apophytes

$9,4,3,2$

apophytes

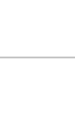

apophytes

Polygonum aviculare L., Polygo-

naceae

Populus balsamifera L., Salicaceae

escaped cultivated fi

plants which infre-

quently naturalize

Populus tremula L., Salicaceae

Potentilla anserina L., Rosaceae

Potentilla erecta (L.) Raeusch.,

Rosaceae

Primula elatior (L.) Hill, Primulacea

Primula veris L., Primulaceae

Prunella vulgaris L., Lamiaceae

Prunus avium L., Rosaceae

cos

$\begin{array}{ll}\text { c } & \text { W } \\ \text { c } & \text { W } \\ \text { c } & \text { W }\end{array}$

$\begin{array}{lr}\text { escaped } & \text { plants } r \\ \text { which commonly }\end{array}$

naturalize

escaped plants

c $\quad$ W

escaped plants

$\begin{array}{ll}c & \text { W } \\ \text { fr } & \text { C }\end{array}$

W

$9,8,6$,

which commonly

naturalize

Prunus cerasus L., Rosaceae

escaped plants

which commonly

naturalize

Prunus domestica L., Rosaceae

escaped cultivated

plants which infre-

quently naturalize

$10,8,2,1 \quad$ anthropophytes

6

10,9,

apophytes

apophytes

apophytes

anthropophytes

apophytes

apophytes

anthropophytes

3

$15 \quad 18$

8

fr C

anthropophytes

12

anthropophytes

C

$r$

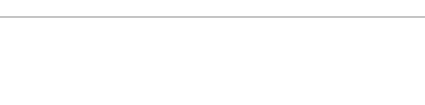




\begin{tabular}{|c|c|c|c|c|c|c|c|c|}
\hline Prunus padus L., Rosaceae & & $\mathrm{c}$ & $\mathrm{W}$ & & hemeradiophores & & 1 & 1 \\
\hline Quercus robur L., Fagaceae & & $\mathrm{c}$ & $\mathrm{W}$ & $10,6,3$ & hemeradiophores $^{\$}$ & 7 & 28 & 35 \\
\hline Ribes nigrum L., Grossulariaceae & & fc & $\mathrm{C}$ & 10,6 & hemeradiophores $^{\$}$ & 29 & 10 & 39 \\
\hline $\begin{array}{l}\text { Ribes rubrum L., Grossulari- } \\
\text { aceae }\end{array}$ & $\begin{array}{l}\text { completely natural- } \\
\text { ized escaped culti- } \\
\text { vated species }\end{array}$ & fr & $\mathrm{C}$ & $10,9,6,3$ & anthropophytes & 2 & & 2 \\
\hline Rosa glauca Pourr., Rosaceae & $\begin{array}{l}\text { escaped plants } \\
\text { which commonly } \\
\text { naturalize }\end{array}$ & fr & $\mathrm{W}$ & 3,1 & anthropophytes & 9 & 5 & 14 \\
\hline $\begin{array}{lll}\text { Rubus } & \text { chamaemorus L., } \\
\text { Rosaceae } & & \end{array}$ & & fr & $\mathrm{W}$ & 10 & hemeradiophores & 3 & & 3 \\
\hline Rubus idaeus L., Rosaceae & & $\mathrm{c}$ & W & $10,6,3,1$ & apophytes & 69 & 28 & 97 \\
\hline Rubus nessensis Hall, Rosaceae & & fr & $\mathrm{W}$ & $10,8,1$ & apophytes & 3 & 1 & 4 \\
\hline $\begin{array}{l}\text { Rumex longifolius DC., Polygo- } \\
\text { naceae }\end{array}$ & & fr & W & $10,9,8,1$ & apophytes & & 1 & 1 \\
\hline $\begin{array}{l}\text { Rumex thyrsiflorus Fingerh., } \\
\text { Polygonaceae }\end{array}$ & & fc & W & $10,9,8,4$ & apophytes & 73 & 3 & 76 \\
\hline Salix viminalis L., Salicaceae & & $\mathrm{c}$ & W & 10,2 & apophytes & 1 & 2 & 3 \\
\hline Salvia officinalis L., Lamiaceae & & & $\mathrm{C}$ & & anthropophytes & 1 & & 1 \\
\hline $\begin{array}{l}\text { Saponaria officinalis L., } \\
\text { Caryophyllaceae }\end{array}$ & $\begin{array}{l}\text { completely natural- } \\
\text { ized escaped culti- } \\
\text { vated species }\end{array}$ & $\mathrm{fc}$ & W & $10,9,8,1$ & anthropophytes & & 1 & 1 \\
\hline $\begin{array}{l}\text { Sedum roseum (L.) Scop., Cras- } \\
\text { sulaceae }\end{array}$ & & & $\mathrm{C}$ & & anthropophytes & & 2 & 2 \\
\hline Sinapis alba L., Brassicaceae & $\begin{array}{l}\text { adventitious species } \\
\text { in the Latvian flora } \\
- \text { ephemerophytes } \\
\text { and neophytes } \\
\text { (archeopytes are } \\
\text { viewed as indige- } \\
\text { nous species); } \\
\text { escaped cultivated } \\
\text { plants which infre- } \\
\text { quently naturalize }\end{array}$ & $\mathrm{r}$ & $\mathrm{P}$ & 9,1 & anthropophytes & & 1 & 1 \\
\hline
\end{tabular}




\begin{tabular}{|c|c|c|c|c|c|c|c|c|}
\hline $\begin{array}{l}\text { Solanum } \quad \text { tuberosum } \quad \text { L., } \\
\text { Solanaceae }\end{array}$ & $\begin{array}{l}\text { cultivated plants } \\
\text { sometimes found } \\
\text { in disturbed areas, } \\
\text { along railways and } \\
\text { on abandoned land }\end{array}$ & fr* & $\mathrm{C}$ & 9,1 & anthropophytes & & 8 & 8 \\
\hline Sorbus aucuparia L., Rosaceae & & $\mathrm{c}$ & $\mathrm{W}$ & 6 & apophytes & 6 & 4 & 10 \\
\hline $\begin{array}{l}\text { Stellaria media (L.) Vill., } \\
\text { Caryophyllaceae }\end{array}$ & & $\mathrm{c}$ & $\mathrm{W}$ & 3 & apophytes & 4 & 4 & 8 \\
\hline $\begin{array}{l}\text { Symphytum asperum Lepech., } \\
\text { Boraginaceae }\end{array}$ & $\begin{array}{l}\text { escaped plants } \\
\text { which commonly } \\
\text { naturalize }\end{array}$ & fr & $\mathrm{C}$ & $10,9,1$ & anthropophytes & & 1 & 1 \\
\hline $\begin{array}{l}\text { Symphytum officinale L., Borag- } \\
\text { inaceae }\end{array}$ & & fc & $\mathrm{W}$ & $10,9,1$ & apophytes & & 1 & 1 \\
\hline Syringa vulgaris L., Oleaceae & $\begin{array}{l}\text { escaped cultivated } \\
\text { plants which infre- } \\
\text { quently naturalize }\end{array}$ & fr & $\mathrm{C}$ & 3 & anthropophytes & & 5 & 5 \\
\hline $\begin{array}{l}\text { Syzygium aromaticum (L.) Merr. } \\
\text { \& L.M.Perry, Myrtaceae }\end{array}$ & & & $\mathrm{C}$ & & anthropophytes & & 1 & 1 \\
\hline $\begin{array}{l}\text { Tanacetum vulgare L., Aster- } \\
\text { aceae }\end{array}$ & & $\mathrm{c}$ & $\mathrm{W}$ & $10,8,1$ & apophytes & & 9 & 9 \\
\hline $\begin{array}{l}\text { Taraxacum officinale (L.) Weber } \\
\text { ex F.H.Wigg., Asteraceae }\end{array}$ & & $\mathrm{c}$ & $\mathrm{W}$ & 7 & apophytes & 15 & 6 & 21 \\
\hline $\begin{array}{l}\text { Thymus serpyllum L., Lami- } \\
\text { aceae }\end{array}$ & & $\mathrm{fc}$ & $\mathrm{W}$ & $8,6,2$ & hemeradiophores & 3 & 2 & 5 \\
\hline Tilia cordata Mill., Malvaceae & & $\mathrm{c}$ & $\mathrm{W}$ & 6,3 & hemeradiophores $^{\$}$ & 13 & 21 & 34 \\
\hline $\begin{array}{l}\text { Trifolium repens L., Legumi- } \\
\text { nosae }\end{array}$ & & $\mathrm{c}$ & $\mathrm{W}$ & $9,8,6,4,1$ & apophytes & 2 & & 2 \\
\hline $\begin{array}{l}\text { Trifolium medium L., Legumi- } \\
\text { nosae }\end{array}$ & & fc & $\mathrm{W}$ & 7 & anthropophytes & 7 & 7 & 14 \\
\hline $\begin{array}{l}\text { Tripleurospermum inodorum } \\
\text { (L.) Sch.Bip., Asteraceae }\end{array}$ & & $\mathrm{c}$ & W & $9,3,1$ & apophytes & & 1 & 1 \\
\hline Tussilago farfara L., Asteraceae & & $\mathrm{c}$ & $\mathrm{W}$ & $\begin{array}{l}10,9,8,3,2, \\
1\end{array}$ & apophytes & 5 & 19 & 24 \\
\hline Urtica dioica L., Urticaceae & & $\mathrm{c}$ & $\mathrm{W}$ & $9,8,6,3,1$ & apophytes & 30 & 35 & 65 \\
\hline $\begin{array}{l}\text { Vaccinium myrtillus L., Eri- } \\
\text { caceae }\end{array}$ & & $\mathrm{c}$ & $\mathrm{W}$ & 10,6 & hemeradiophores & 83 & 22 & 105 \\
\hline $\begin{array}{l}\text { Vaccinium oxycoccos L., Eri- } \\
\text { caceae }\end{array}$ & & fc & $\mathrm{W}$ & 10 & hemerophobes & 43 & 11 & 54 \\
\hline
\end{tabular}




\begin{tabular}{|c|c|c|c|c|c|c|c|c|}
\hline $\begin{array}{l}\text { Vaccinium uliginosum L., Eri- } \\
\text { caceae }\end{array}$ & & fc & $\mathrm{W}$ & 10,6 & hemeradiophores & 11 & 1 & 12 \\
\hline $\begin{array}{l}\text { Vaccinium vitis-idaea L., Eri- } \\
\text { caceae }\end{array}$ & & $\mathrm{c}$ & $\mathrm{W}$ & $10,6,3$ & hemeradiophores & 47 & 9 & 56 \\
\hline $\begin{array}{l}\text { Valeriana officinalis L., Caprifo- } \\
\text { liaceae }\end{array}$ & & $c^{*}$ & $\mathrm{~W}$ & 10,6 & apophytes & 2 & 16 & 18 \\
\hline $\begin{array}{l}\text { Verbascum thapsus L., Scrophu- } \\
\text { lariaceae }\end{array}$ & & fr & $\mathrm{W}$ & $4,7,2,1$ & apophytes & 1 & 1 & 2 \\
\hline Viburnum opulus L., Adoxaceae & & fc & $\mathrm{C} / \mathrm{W}$ & 10,6 & apophyte & 4 & 10 & 14 \\
\hline Vicia faba L., Leguminosae & $\begin{array}{l}\text { cultivated plants } \\
\text { sometimes found } \\
\text { in disturbed areas, } \\
\text { along railways and } \\
\text { on abandoned land }\end{array}$ & $\mathrm{r}^{*}$ & $\mathrm{C}$ & & anthropophytes & & 1 & 1 \\
\hline \multirow[t]{2}{*}{ Viola tricolor L., Violaceae } & & fc & $\mathrm{W}$ & $8,4,2$ & anthropophytes & & 2 & 2 \\
\hline & & & & & Total & 895 & 841 & 1736 \\
\hline
\end{tabular}

